\title{
K4D's work on conflict, violence, and peace (2016-2021)
}

Siân Herbert ${ }^{1}$

GSDRC \& K4D, University of Birmingham

January 2022

\section{Contents}

1. Introduction

2. Thematic grouping of the reports

3. Request type and analytical focus

4. Forms of conflict, violence, and/or peace addressed by the reports

5. Origin of research requests - FCDO Cadres and teams

6. Intended use of reports

7. Geography

8. Feedback

9. Annex

10. References

\footnotetext{
${ }^{1}$ With thanks to Dwi Rachmawati and Zenobia Ismail for data assistance and Roz Price for peer review.
}

The K4D helpdesk service provides brief summaries of current research, evidence, and lessons learned. Helpdesk reports are not rigorous or systematic reviews; they are intended to provide an introduction to the most important evidence related to a research question. They draw on a rapid deskbased review of published literature and consultation with subject specialists. Government departments, but the views and opinions expressed do not necessarily reflect those of DFID, the UK Government, K4D or any other contributing organisation. For further information, please contact helpdesk@k4d.info. 


\section{Introduction}

The Knowledge, Evidence and Learning for Development Programme (K4D) provides access to all FCDO staff to recent research and evidence. The programme has produced over 1000 rapid evidence syntheses (helpdesk queries (HDQ)), 40 emerging issues reports (EIR), and run 40 learning journeys (LJs) from 2016 to 2021. In K4D's previous iterations, the Helpdesk has been providing evidence and knowledge services to the UK Government since 2001.

The rapid nature of the K4D service and its flexibility means that it is responsive to emerging events, crises, and policy changes, as has been demonstrated e.g. through its work on COVID19 (Quak, 2021; Herbert, 2021) and climate change (Price, 2021). Conflict, violence, and peace has been the focus of many evidence requests and much of the learning activity of K4D, in line with FCDO's and formerly DFID's development commitments to fragile and conflict affected contexts (FCAS).

This report provides an illustrative overview of K4D's work from October 2016 until May 2021 connected to conflict (as broadly defined - see "Definition of conflict" below). It is not an analysis of conflict per se, but of the research that FCDO (and formerly DFID) have commissioned K4D to write on conflict over the past four years. It is illustrative and based on a rapid review of a sample of papers, and thus should not be considered exhaustive or in-depth. Given the breadth of K4D's reports on this area, this report draws on a selection of 68 reports (see "Approach" below). This report will be used as input for a K4D-FCDO learning event on conflict, violence, and peace to take place in Autumn 2021.

\section{Summary}

The research requests that $K 4 \mathrm{D}$ receives cover a wide range of subjects. The 68 papers in this sample all focus on, or in some way address conflict, violence, and/or peace. The sample includes papers that explicitly focus on conflict, violence and/or peace, as well as papers that focus on other issues within a FCAS context. A number of categorisations have been provided to explore different aspects of this sample of requests. Where possible examples of queries have been given to illustrate the various categorisations.

Thematic group - Most reports were classified under more than one thematic group, the most common were: conflict (60 of 68 reports); social development (23 reports); governance (20); humanitarian (9); health (6); livelihoods (6); climate and environment (4); economist (4); education (4); and private sector development (1).

Request type and analytical focus - More papers were focussed on analysis of interventions (33 reports), compared to analysis of the context (conflict analysis) (26 reports). Nine reports covered both.

- Context/conflict analysis reports - Within this category, reports focussed on: geographic context (25 reports out of 68); conflict dynamics/trends/scenarios (21 reports); conflict causes/drivers (21); and conflict actors (14). With some reports including more than one of these focus areas.

- Intervention analysis - Within this category, the reports have a wide-range of focus areas, including: examples; mapping; impact; what's worked/hasn't worked; effectiveness; lessons; challenges; principles; best practice; gaps; risks and opportunities; how to improve; scalability; implementation/delivered; monitoring and 
evaluation; and coordination. Although many of these focus areas overlap significantly, each term does bring a different emphasis.

Forms of conflict, violence, and/or peace addressed by the reports - Most reports touched on multiple forms. The most common forms were: conflict (general) (30 of 68 reports); peacemaking/building (14 reports); stability/instability (12); violence (general) (10); political violence and armed conflict (10); peace process (7); state violence (6); gender-based violence (GBV) (6); extremism (6); resilience (5); protest and unrest (4); mediation and negotiations (4); interpersonal violence (3); and social cohesion (2).

Origin of research requests - The most common FCDO Cadres that requested research on conflict from K4D were: conflict (26 of 68 reports); other government departments (18 reports); social development (7); humanitarian (5); governance (3); and statistics (2). Requests were spread pretty evenly over a large number of teams -42 teams in total for the 68 reports in the sample. The top 6 requesting teams were: Stabilisation Unit (6 report requests out of 68 ); Afghanistan (4 requests); Yemen (4); Conflict, Security and Justice Group (3), Heads of Profession (3), and STAR MENA \& Asia team (3).

Intended use of reports - The biggest share of reports relating to conflict, violence, and/or peace were requested to: inform programme design and/or to develop a business case for an intervention or programme (22 reports out of 68 ); scoping/syntheses of evidence (10 reports); inform policy work (10); feed into larger piece of work (10); and support a meeting/event (2).

Geography - Almost half of the requests (33) take a general focus, where no region or country is mentioned. Following that, the most common regions of focus were: Middle East and North Africa (MENA) (17 reports out of 68); Sub-Saharan Africa (SSA) (13 reports); South Asia (8); Multiregion (6); Europe and Central Asia (5); East Asia and Pacific (4); and Latin America and the Caribbean (4). The reports have a wide country coverage, with 38 countries mentioned in total in research titles or research questions.

Feedback - The Helpdesk reports in this selection received relatively low feedback via the evaluation form (at 16\%) compared to the average response for K4D Helpdesk reports (at around $35 \%$ ). The 11 responses ranked the papers as: excellent ( 6 out of 11 responses); very good (4 responses); and good (1).

\section{Methodology}

\section{Approach of this rapid review}

The selection of K4D outputs on conflict was based on an extensive search in the K4D repository of titles and research questions using NVIVO. The Annex shows all K4D outputs included in this report (with information on the type of query, geographical region (based on World Bank region definitions), and FCDO intended use). The titles of the unpublished papers have been removed. Specifically, this paper was prepared by reviewing a sub-section of K4D outputs between October 2016 - May 2021 that are relevant to the theme of conflict, identified through key word searches using the NVIVO platform. Key words included: conflict, violence, war, peace, extremism, radicalisation, terrorism, fighters, combatants, armed, troops, rebel, gang, military, police, gendarmerie, ceasefire, demobilisation, disarmament, FGM, "female genital mutilation", SGBV, rape, unrest, FCAS, fragile, instability, insecurity, grievance, compact, and "social cohesion". Both published and unpublished outputs were included. 
A large number of HDQs and EIRs were initially identified using this method (about 800 papers), these were further reduced by restricting the initial sub-section to reports with 60 or more points of reference to the above key words. This produced a selection of 264 reports, roughly a $26 \%$ sample of the overall number of Helpdesk and Emerging Issue reports produced as of $1^{\text {st }}$ June 2021. In line with the two other reports produced in this series, this selection was reduced to 100 reports - a $10 \%$ sample - through selecting the 100 reports that included most references to the key words. A further 32 reports were excluded from this section after being deemed not relevant based on a scan of the report's summary and the expert knowledge of the researcher. The final section for this overview report is therefore 68 papers -63 HDQs (of which 43 are single HDQs (with six-days of research allocated) and 20 are multiple HDQs (with more than six days of research allocated but produced in one report)) and 5 are EIRs (with variable days allocated from 12-days and upwards).

This selection includes papers that (a) focus on conflict and/or violence, as well as papers that (b) focus on issues within a conflict or violence context. It does this as: both categories are relevant to understand FCDO's requests on conflict; due to the sample selection strategy being based on keyword searches through NVIVO; and as it would complicate the selection of papers to remove reports based on whether and how explicit their focus is on conflict.

Of the three papers in this series that explore K4D's work, this paper is the most diverse in terms of thematic coverage as: conflict features not just as an issue of focus, but also as a context; as conflict has a wide application, depending on one's definition and perspective (see below); and as conflict is well-established as a core focus of FCDO's work, and DFID's work before that, thus the key word searches brought up a large number of papers that cover diverse topics.

Given the size of the selection and the relatively short timeframe of the K4D programme, it is not possible to identify trends over time. Therefore, this paper provides an illustrative overview of the conflict theme (based on the section of 68 reports), highlighting some thematic topics of focus and case studies, rather than providing a comprehensive analysis of all outputs on the selected theme. There are a number of limitations to this methodology, including the effect of the length of the paper, with longer papers biased towards having more (key) words. The data itself is only as strong as the data that is provided to us by advisers and FCDO and this can be limited given the rapid nature of the service - so for example, information on the intended purpose of a report, or which team an adviser is from can only be gleaned from information given by advisers or from emails. The data has been cleaned where possible using information from the logging of other HDQs. Where possible we have tried to identify key events, or uses the reports have fed into, but again this is based on the information we have been given. Lastly, the analysis provided on thematic grouping and analytical focus are for illustrative purposes only, they are basic (e.g. the thematic grouping is based on FCDO Cadre categories) and not robust, however, they enable a discussion through the standardisation of the vast array of K4D reports and topics.

\section{Definition of conflict}

This report takes a broad understanding of conflict that draws on two elements. Firstly, it understands conflict as a phenomenon that occurs at all levels, including the interpersonal level, as well as the group/community, national, and international levels. This means that household violence, interpersonal attacks, and criminal violence are analysed alongside political violence and armed conflict. Secondly, it takes a broad view by understanding there to be a "continuum of violence" (Cockburn, 2004) that includes personal/direct violence, structural/indirect violence, 
and cultural violence (the use of culture to legitimise violence) (Galtung, 1969, 1990). This means that latent conflict (conflict that is below the surface with potential to emerge) is analysed alongside surface conflict (conflict that is visible but shallow), and open conflict (conflict that is very visible and deep-rooted) (Fisher et al., 2000; Herbert, 2017). This broad approach recognises: the increasing evidence of the complex interlinkages between the different forms of violence and conflict (for example, gender inequality and armed conflict) and the need to bridge the silos between these areas for more effective policymaking; the value of analysing the broader violence context to enable early warning, preventative approaches to peacebuilding, and a resilience approach; and the limitations of the traditional hierarchy between state and human security (Herbert, 2014; Bjarnegård, et al., 2020; Carbonari, et al., 2020). Bearing in mind more traditional definitions of "conflict", for clarity, this rapid review simultaneously refers to "conflict, violence, and/or peace" and/or "conflict" in regards to the scope of this paper.

\section{Thematic grouping of the reports}

Helpdesk requests cover a wide range of subjects. The 68 papers in this sample all focus on, or in some way address conflict, violence, and/or peace. The sample includes papers that explicitly focus on conflict, violence and/or peace, as well as papers that focus on other issues within a FCAS context (See Figure 1 for examples).

Figure 1: Examples of reports that focus on conflict compared to those that focus on an issue in a FCAS context

\begin{tabular}{|l|l|}
$\begin{array}{l}\text { Report focus } \\
\begin{array}{l}\text { Explicit focus on } \\
\text { conflict, violence, } \\
\text { and/or peace }\end{array}\end{array}$ & $\begin{array}{l}\text { What is the evidence telling us about the immediate and medium/longer- } \\
\text { term impacts of COVID-19 on conflict and security (e.g. peace, mediation, } \\
\text { conflict prevention, peacekeeping) across the region? }\end{array}$ \\
\hline $\begin{array}{l}\text { Focus on issues } \\
\text { within a conflict, } \\
\text { violence, and/or } \\
\text { peace context }\end{array}$ & $\begin{array}{l}\text { What are the different forms of social capital existing in Yemen and the } \\
\text { extent to which such social capital helps or hinders the ability of individuals, } \\
\text { households and communities to cope with the current humanitarian crisis in } \\
\text { Yemen. Please include section covering definitions of social capital. }\end{array}$ \\
\hline
\end{tabular}

The sample was classified into broad thematic groups based on the reports' research questions, and in some cases, where the information in the research questions is limited, also the overview of the report. The categories for the thematic groups are based on the FCDO's Cadre system (also known as the "cadre" system) (see Figure X below for detail on the focus areas of the different Cadres).

Most reports were classified under more than one thematic group, demonstrating the multidisciplinary and interdisciplinary nature of most of the reports, and also the generally broad scope of the reports. Ultimately, this categorisation is illustrative, being based on the author's interpretation, and is not conclusive.

The most common thematic area that the reports address was, unsurprisingly, conflict, with overall 60 of 68 reports categorised as having conflict, violence and/or peace as a core theme. The 8 papers that did not include conflict as a core focus tend to be those situated in a FCAS context, as explained in Figure 1 above (e.g. the paper on social capital in Yemen). After conflict, the other most common themes in the reports were: social development (a core theme in 23 of 
68 of the reports); and governance (20 of 68 papers). The less common themes include: humanitarian (9 of 68 reports); health (6); livelihoods (6); climate and environment (4); economist (4); education (4); and private sector development (1) (see Figures 2, 3 and 4).

As these reports vary significantly in size - with many being 6-day HDQs, and some being much larger multi-HDQs and EIRs - the numbers below do not directly represent the time spent on the different thematic areas identified, or the importance of these issues, or their weighting. The single HDQs are focussed on fewer subjects and have fewer research questions - e.g. see the papers listed in the Annex on border disputes and micro-conflicts in South/South-East Asia, or on the war economy in North East Nigeria. The papers that are classified as multiple HDQs and EIRs, provide broader analyses and include more research questions e.g. see the conflict analysis of North Eastern Kenya listed in the Annex.

Figure 2: Number of reports by core thematic area

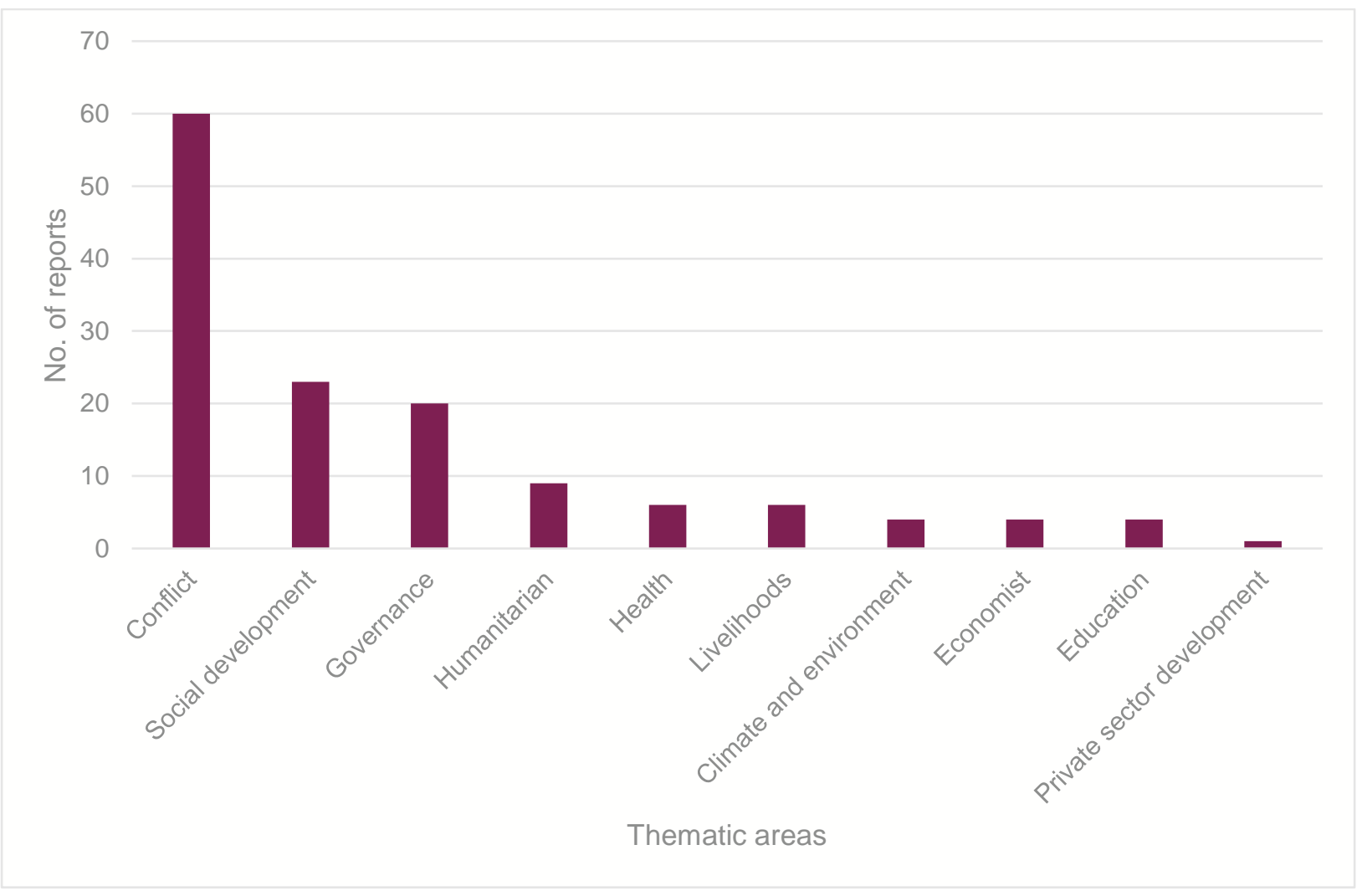

Figure 3: Number of reports by core thematic area and examples
Core thematic area of
reports (using the
No. of
Example of research question
FCDO Cadre system) ${ }^{2}$

\footnotetext{
${ }^{2}$ See Figure 4 for details of the FCDO Cadre system

${ }^{3}$ Most reports were classified under more than one thematic group
} 


\begin{tabular}{|c|c|c|}
\hline Conflict & 60 & $\begin{array}{l}\text { What are the current and projected trends around conflict } \\
\text { and stability in the South and South East Asia with respect } \\
\text { to the following drivers of conflict? } \\
\text { - Climate change as a driver of conflict and migration } \\
\text { - Serious organised crime, and } \\
\text { - COVID } 19 \text { and economic shocks }\end{array}$ \\
\hline Social development & 23 & $\begin{array}{l}\text { What risks/vulnerabilities do women and girls with } \\
\text { disabilities affected by conflict and crises face? What is the } \\
\text { available evidence on interventions to support women and } \\
\text { girls with disabilities affected by conflict/crises? }\end{array}$ \\
\hline Governance & 20 & $\begin{array}{l}\text { What evidence is there for what works to maintain essential } \\
\text { state functions and basic service delivery in escalating } \\
\text { conflict situations? Focus on modalities and lessons from } \\
\text { contexts like Afghanistan, Yemen, Somalia, and Syria. }\end{array}$ \\
\hline Humanitarian & 9 & $\begin{array}{l}\text { What examples and evidence is there of humanitarian } \\
\text { pauses and corridors in conflict contexts and where they } \\
\text { worked, what was the process for their creation? What } \\
\text { guidance is available on establishing such humanitarian } \\
\text { pauses or corridors in conflict situations? }\end{array}$ \\
\hline Health & 6 & $\begin{array}{l}\text { What is the evidence telling us about the immediate and } \\
\text { medium/longer-term impacts of COVID-19 on conflict and } \\
\text { security (e.g. peace, mediation, conflict prevention, } \\
\text { peacekeeping) across the East Africa region? }\end{array}$ \\
\hline Livelihoods & 6 & $\begin{array}{l}\text { What are the impacts of different approaches to supporting } \\
\text { agriculture in protracted crises and rebuilding agriculture } \\
\text { after conflict? }\end{array}$ \\
\hline $\begin{array}{l}\text { Climate and } \\
\text { environment }\end{array}$ & 4 & $\begin{array}{l}\text { What is the evidence base on climate change as a driver of } \\
\text { conflict in Afghanistan and other Fragile and Conflict } \\
\text { Affected States (FCAS)? }\end{array}$ \\
\hline Economist & 4 & $\begin{array}{l}\text { What economic interventions/tools supported by } \\
\text { international actors, including international financial } \\
\text { institutions, have delivered short term stability to manage } \\
\text { popular unrest between protestors and the state? }\end{array}$ \\
\hline Education & 4 & $\begin{array}{l}\text { Provide an up-to-date report based on available evidence } \\
\text { that includes: What has worked/hasn't worked in reducing } \\
\text { and preventing school-related violence, and in addressing } \\
\text { school-related violence when it happens? What measures } \\
\text { have worked best to promote safe, inclusive and violence- } \\
\text { free schools? What factors have been critical in securing } \\
\text { positive change? }\end{array}$ \\
\hline $\begin{array}{l}\text { Private sector } \\
\text { development }\end{array}$ & 1 & $\begin{array}{l}\text { What economic interventions/tools supported by } \\
\text { international actors, including international financial }\end{array}$ \\
\hline
\end{tabular}


institutions, have delivered short term stability to manage

popular unrest between protestors and the state?

Source: Author's interpretation drawing on K4D data

The FCDO's Cadre system is a succession of the model established by DFID, and it provides the organisational framework for most of FCDO's work related to international development. Figure 4 collates the staff competencies detailed in the FCDO's technical competency frameworks. For this report, the competencies are used as a proxy to identify the thematic focus of each Cadre.

Figure 4: FCDO thematic Cadres and competencies ${ }^{4,5}$

\section{FCDO Cadre Competencies}

Climate change impacts, adaptation and resilience; low carbon development and climate change mitigation; environmental stewardship, including natural

Climate and environment resource management, resource scarcity, ecosystem services and pollution; climate and environment science; environmental management systems; climate and environmental governance, nationally and internationally; and environment and climate finance.

Primary competencies: applied conflict and political analysis; conflict sensitivity; and conflict response: building peace and stability.

Competency specialisms: climate, environment and natural resource management; inclusive economic development; legacies of armed conflict including transitional justice; migration, serious and organised crime; peace processes including conflict resolution mechanisms; violent extremism; and security, justice and human rights.

Macroeconomic knowledge; microeconomic knowledge; international

Economist economics; econometrics and data; and effective communication for economists.

Education

Education policy; education systems; global education system; equity and education; and research, evidence and innovation.

Core competency: applied governance and political economy analysis. Specialist competencies: accountable and inclusive politics; public sector

Governance governance and service delivery; inclusive growth and economic development; public financial management and domestic revenue mobilisation; anticorruption; and security, justice and human rights.

Public health; health systems development; health architecture; health improvement and wider determinants of health; evidence, innovation and

\footnotetext{
4 This figure only includes the thematic Cadres as it seeks to identify themes in FCDO's requests to K4D. It excludes the Cadres of: evaluation; programme delivery; and statistics.

${ }^{5}$ Notably the Cadre competency descriptions are not written in a standardised way having varying levels of detail e.g. with some specifying core and specialism competencies, and others just specifying general competencies. They are therefore not exactly comparable and provide an indicative guide to the thematic scope/lens of work of the Cadre. Some competencies are stated in multiple Cadres.
} 


\begin{tabular}{|l|l|}
\hline Humanitarian & $\begin{array}{l}\text { evaluation; and protracted crises, fragile-and-conflict-affected-states and } \\
\text { nutrition. }\end{array}$ \\
\hline $\begin{array}{l}\text { Planning and managing relief operations; humanitarian theory and architecture; } \\
\text { international humanitarian law and principles; and crisis risk and resilience. }\end{array}$ \\
\hline $\begin{array}{l}\text { Infrastructure for sustainable development and UK aid delivery; infrastructure } \\
\text { policy, governance and finance; infrastructure implementation and delivery and } \\
\text { operation; infrastructure users and beneficiaries; infrastructure effects on and } \\
\text { response to the environment, natural disasters and the climate crisis; } \\
\text { infrastructure response in fragile and conflict affected situations, humanitarian } \\
\text { crises and different contexts; and infrastructure and urban sectors, options and } \\
\text { technology; }\end{array}$ \\
\hline $\begin{array}{l}\text { Primary competencies: Climate-smart \& resilient agriculture, food systems \& } \\
\text { markets; building resilience and managing risks to shocks and stresses; } \\
\text { supporting transition, transformation and innovation; politics, governance and } \\
\text { enabling environment for sustainable natural resource and environmental } \\
\text { management and markets; nutrition and food security; and jobs and incomes. }\end{array}$ \\
\hline $\begin{array}{l}\text { Specialism competencies: women's economic empowerment; and graduation } \\
\text { from poverty and social protection. }\end{array}$ \\
\hline $\begin{array}{l}\text { Private } \\
\text { sector } \\
\text { development }\end{array}$ & $\begin{array}{l}\text { Economic development, inclusive growth and poverty reduction; private sector } \\
\text { contribution to development; investment and finance; investment climate } \\
\text { reform; market systems development; and trade and development. }\end{array}$ \\
\hline Social & $\begin{array}{l}\text { Social policy (social and political analysis and inclusion); poverty and } \\
\text { vulnerability analysis and monitoring; gender equality and the rights and } \\
\text { empowerment of women and girls; empowerment and accountability; and social } \\
\text { protection. }\end{array}$ \\
\hline
\end{tabular}

Source: Information extracted from the FCDO technical competency frameworks for each Cadre, updated in May 2020, https://www.gov.uk/government/publications/dfid-technical-competency-frameworks

Besides the broad thematic focus, each Cadre also differs in its analytical lens. This is illustrated in Figure 5 below through the examples of the three most common thematic areas found in these reports - conflict, social development, and governance Cadres. For example, each Cadre differs in terms of what it considers its end goal (resilience to conflict and instability; poverty reduction; or governance change), and in its object of interest (the causes and drivers of conflict and instability; social, cultural, political and economic structures, dynamics, norms and power relations; or political systems, core governance concepts and global, regional and transnational drivers of governance change). These different lenses are useful to consider as a HDQ request by one cadre may focus on a common subject to another cadre but differ in its framing and object of interest. Thus, this is also interesting when examining the cadres that request more HDQs, compared to those that request few.

Figure 5: How FCDO's conflict, social development, and governance Cadres differ in their analytical lens 


\begin{tabular}{|l|l|}
\hline $\begin{array}{l}\text { FCDO } \\
\text { Cadres }\end{array}$ & $\begin{array}{l}\text { Analytical lens (as based on the FCDO's Cadre technical competency } \\
\text { frameworks) }\end{array}$ \\
\hline Conflict & $\begin{array}{l}\text { Applied conflict and political analysis: An advisor can undertake robust conflict } \\
\text { analysis examining the causes and drivers of conflict and instability, including } \\
\text { the centrality of political settlements, regional geopolitics and transnational } \\
\text { drivers and the factors that sustain resilience. }\end{array}$ \\
\hline $\begin{array}{l}\text { Social } \\
\text { development }\end{array}$ & $\begin{array}{l}\text { Social policy (social and political analysis and inclusion): An Advisor can } \\
\text { undertake robust Social Analysis examining the social, cultural, political and } \\
\text { economic structures, dynamics, norms and power relations that include or } \\
\text { exclude people, and drive or constrain poverty reduction. }\end{array}$ \\
\hline Governance & $\begin{array}{l}\text { Applied governance and political economy analysis: Understand governance } \\
\text { evidence, policy and practice in a range of settings; demonstrates knowledge of } \\
\text { political systems, core governance concepts and global, regional and } \\
\text { transnational drivers of governance change. }\end{array}$ \\
\hline
\end{tabular}

Source: Information extracted from the FCDO technical competency frameworks for each Cadre, updated in May 2020, https://www.gov.uk/government/publications/dfid-technical-competency-frameworks

\section{Request type and analytical focus}

As conflict is a very broad topic, the papers included in this sample are extremely diverse in their thematic, geographic, and analytical focus. Thus, there is no simple or single way to analyse these papers.

One way to explore the focus of these reports is to distinguish between those that focus on: (a) a conflict-specific thematic issue, or conflict with a specific geographic or actor context (herein "context/conflict analysis"); and those that focus on (b) analysis of policy interventions (herein "intervention analysis"). Analysis of the 68 sample of papers found that more papers were focussed on (b) intervention analysis (33 papers), compared to (a) context analysis (26 papers). There were a few papers that covered both (a) context/conflict analysis and (b) intervention analysis (9 papers), though in general this is limited as most of the reports in this sample are rapid HDQs with only six days of researcher work.

Figure 6: Number of papers focusing on context analysis compared to intervention analysis

\begin{tabular}{|l|l|l|l|}
\hline $\begin{array}{l}\text { Analytical focus } \\
\text { of reports }\end{array}$ & $\begin{array}{l}\text { No. of } \\
\text { reports }\end{array}$ & Description & Example of research question \\
\hline $\begin{array}{l}\text { Context/conflict } \\
\text { analysis }\end{array}$ & 26 & $\begin{array}{l}\text { Reports focusing on a } \\
\text { conflict-specific thematic } \\
\text { issue, and sometimes }\end{array}$ & $\begin{array}{l}\text { What are the current and projected } \\
\text { impacts of climate change on regional } \\
\text { stability, prosperity, and security in } \\
\text { North Africa? }\end{array}$ \\
\hline
\end{tabular}

\footnotetext{
${ }^{6}$ For this report, the competencies listed in the FCDO's Cadre technical competency frameworks are used as a proxy for the thematic focus and analytical lens of each Cadre. Figure $\mathrm{X}$ lists the first competency listed in the frameworks for: conflict; social development; and governance.
} 


\begin{tabular}{|c|c|c|c|}
\hline & & $\begin{array}{l}\text { also in a specific } \\
\text { geographic location. }\end{array}$ & \\
\hline $\begin{array}{l}\text { Intervention } \\
\text { analysis }\end{array}$ & 33 & $\begin{array}{l}\text { Reports focusing on } \\
\text { policy interventions } \\
\text { related to conflict, or in a } \\
\text { FCAS context. }\end{array}$ & $\begin{array}{l}\text { What interventions related to policing in } \\
\text { fragile and conflict affected states have } \\
\text { caused harm to marginalised groups or } \\
\text { resulted in negative unintended } \\
\text { consequences? }\end{array}$ \\
\hline $\begin{array}{l}\text { Context/conflict } \\
\text { analysis and } \\
\text { intervention } \\
\text { analysis }\end{array}$ & 9 & $\begin{array}{l}\text { Reports focusing on both } \\
\text { a conflict-specific } \\
\text { thematic issue (and } \\
\text { sometimes also in a } \\
\text { specific geographic } \\
\text { location) as well as } \\
\text { policy interventions } \\
\text { related to conflict, or in a } \\
\text { FCAS context. }\end{array}$ & $\begin{array}{l}\text { Current trends in violent conflict - } \\
\text { Summarise the key findings in terms of } \\
\text { drivers, responses and themes, and } \\
\text { how and why these are changing over } \\
\text { time. }\end{array}$ \\
\hline
\end{tabular}

Source: Author's interpretation drawing on K4D data

\section{Analytical focus of the reports}

\section{Context/conflict analysis reports}

Within the category of "context/conflict analysis", and drawing on the widely-used conflict analysis analytical model (e.g. see Herbert, 2017), it is possible to further distinguish between reports according to their focus on: (a) conflict actors; (b) conflict dynamics/trends/scenarios; (c) conflict causes/drivers; and (d) geographic context. Each report categorised under "context/conflict analysis" includes at least one of these focus areas, and some include more than one focus area. See Figure 7 for examples, and Example 1 for a summary of findings from the HDQ "Conflict analysis of Bangladesh".

Figure 7: Number of papers focussing on elements of conflict analysis

\begin{tabular}{|c|c|c|c|}
\hline $\begin{array}{l}\text { Focus of } \\
\text { context/conflict } \\
\text { analysis reports }\end{array}$ & $\begin{array}{l}\text { No. of } \\
\text { reports }\end{array}$ & Description & Example of research question \\
\hline Actors & 14 & $\begin{array}{l}\text { Reports that focus on } \\
\text { specific actors relating to } \\
\text { conflict, violence, or } \\
\text { peace }\end{array}$ & $\begin{array}{l}\text { What are the different groups involved } \\
\text { in extremist, violent extremism and } \\
\text { terrorism in Yemen? }\end{array}$ \\
\hline $\begin{array}{l}\text { Dynamics/ } \\
\text { trends/ } \\
\text { scenarios }\end{array}$ & 21 & $\begin{array}{l}\text { Reports that focus on } \\
\text { dynamics, trends, and/or } \\
\text { scenarios relating to } \\
\text { conflict, violence, or } \\
\text { peace }\end{array}$ & $\begin{array}{l}\text { What are the trends and developments } \\
\text { relating to border disputes and micro- } \\
\text { conflicts in South/South-East Asia? }\end{array}$ \\
\hline
\end{tabular}




\begin{tabular}{|l|l|l|l|}
\hline & & $\begin{array}{l}\text { Reports that focus on } \\
\text { the causes of conflict, } \\
\text { violence, and/or } \\
\text { resilience }\end{array}$ & $\begin{array}{l}\text { What roles do livestock play in South } \\
\text { Sudan's violent conflicts? What are the } \\
\text { drivers and dynamics of this? What is } \\
\text { the impact of conflict on the livestock } \\
\text { sector in South Sudan? }\end{array}$ \\
\hline $\begin{array}{l}\text { Geographic } \\
\text { context }\end{array}$ & 25 & $\begin{array}{l}\text { Reports that focus on a } \\
\text { specific geographic } \\
\text { context }\end{array}$ & $\begin{array}{l}\text { What narratives are prominent in Mostar } \\
\text { and what role do narratives of ethnicity } \\
\text { play in building, maintaining or } \\
\text { challenging post-conflict divisions? }\end{array}$ \\
\hline
\end{tabular}

Source: Author's interpretation drawing on K4D data

\section{Example 1: context/conflict analysis in a multi-HDQ}

This report focused on three of the four elements listed in Figure 7:

dynamics/trends/scenarios; causes/drivers; and geographic context.

Herbert, S. (2019). Conflict analysis of Bangladesh. K4D Helpdesk Report 599. Brighton, UK: Institute of Development Studies

https://opendocs.ids.ac.uk/opendocs/handle/20.500.12413/15377

This helpdesk report examines the root causes and dynamics of conflict and (in)stability in Bangladesh. The report finds that Bangladesh has a violent political culture, and has experienced widespread political violence, especially around elections. This is a feature of its increasingly authoritarian democracy. Bangladesh now exhibits 'partyarchy' and dynastic rule, which stymies regime succession and democratic consolidation, and which fosters political instability. It faces other political challenges related to justice and corruption, complex gendered violence around election and democratic processes, the Rohingya crisis, extremism, the Chittagong Hill Tracts conflict, and the Bangladesh-India border.

In terms of social cleavages, social, ethnic and religious conflicts have flared when exploited for political purposes, but are mostly latent. The most important schism is on the issue of the role of religion in politics and national identity. While Bangladesh has a tradition of a vocal and active civil society, civil society space is closing.

Bangladesh faces serious environmental challenges, being highly disaster prone and as one of the countries most at risk from climate change.

In terms of economic (in)stability, Bangladesh is generally heralded as an economic development success story, compared to most other South Asian economies. And though it has performed 'spectacularly' in progress towards the Millennium Development Goals, poverty and inclusive growth continue to be a major problem, complicating its transition from lower to upper middle-income status. The main risk to economic stability is widely identified as its poor institutional and governance landscape. 


\section{Intervention analysis reports}

Under the category "intervention analysis", the reports have a wide-range of focus areas, including: examples of interventions; mapping of interventions; impact of interventions; what's worked/hasn't worked; effectiveness; lessons; challenges; principles; best practice; gaps; risks and opportunities; how to improve; scalability; whether/how interventions have been implemented/delivered; monitoring and evaluation of interventions; and coordination among actors. Although many of these focus areas overlap significantly, each term does bring a different emphasis - e.g. a report looking at "the challenges in delivering education for girls in FCAS" would slightly differ to a report looking at lessons from delivering education for girls in FCAS. And a report looking at "the effectiveness of transparency and accountability interventions in FCAS" would slightly differ to a report looking at what's worked in improving transparency and accountability in FCAS. Each report categorised under "intervention analysis" includes at least one of these focus areas, and many reports include more than one focus area. See Figure 8 for examples. As these categories overlap substantially, the below figure does not quantify how many reports address each area.

Figure 8: Examples of intervention analysis reports

\begin{tabular}{|c|c|}
\hline $\begin{array}{l}\text { Focus of } \\
\text { intervention } \\
\text { analysis reports }\end{array}$ & Example of research question \\
\hline Examples & $\begin{array}{l}\text { What examples and evidence is there of humanitarian pauses and corridors } \\
\text { in conflict contexts and where they worked, what was the process for their } \\
\text { creation? What guidance is available on establishing such humanitarian } \\
\text { pauses or corridors in conflict situations? }\end{array}$ \\
\hline Mapping & $\begin{array}{l}\text { 1. Catalogue and classify the } 33 \text { items already identified in the } 2013 \text { report } \\
\text { [on the] Humanitarian Protection of persons affected by conflict } \\
\text { (https://www.gov.uk/dfid-research-outputs/scoping-study-what-works-in- } \\
\text { protection-and-how-do-we-know) } \\
\text { 2. Initial rapid evidence map (nature and spread of evidence) regarding the } \\
\text { research of the humanitarian protection of persons affected by conflict }\end{array}$ \\
\hline Impact & $\begin{array}{l}\text { What are the impacts of different approaches to supporting agriculture in } \\
\text { protracted crises and rebuilding agriculture after conflict? }\end{array}$ \\
\hline $\begin{array}{l}\text { What's } \\
\text { worked/hasn't } \\
\text { worked }\end{array}$ & $\begin{array}{l}\text { What has worked/hasn't worked in reducing and preventing school-related } \\
\text { violence, and in addressing school-related violence when it happens? What } \\
\text { measures have worked best to promote safe, inclusive and violence-free } \\
\text { schools? What factors have been critical in securing positive change? }\end{array}$ \\
\hline Effectiveness & $\begin{array}{l}\text { What is known about the impact and effectiveness of transparency and } \\
\text { accountability interventions in fragile and conflict affected contexts? What } \\
\text { knowledge gaps exist for future research? }\end{array}$ \\
\hline Lessons & $\begin{array}{l}\text { What lessons or evidence is there from previous or ongoing efforts to } \\
\text { establish joint operating principles agreed by humanitarian actors to improve } \\
\text { humanitarian access and what factors contributed to their success or failure? }\end{array}$ \\
\hline
\end{tabular}




\begin{tabular}{|l|l|}
\hline Challenges & $\begin{array}{l}\text { What are the lessons learned from Preventing and Countering Violent } \\
\text { Extremism (P/CVE) programming implemented amid ongoing conflict globally? } \\
\text { Please focus on what has worked and what were the challenges in delivering } \\
\text { interventions addressing "push" and "pull" factors. }\end{array}$ \\
\hline Best practice & $\begin{array}{l}\text { What lessons or best practices are available regarding gender-sensitive } \\
\text { security and justice interventions in Sub-Saharan Africa, MENA and South } \\
\text { Asia? }\end{array}$ \\
\hline Gaps & $\begin{array}{l}\text { What is known about the impact and effectiveness of transparency and } \\
\text { accountability interventions in fragile and conflict affected contexts? What } \\
\text { knowledge gaps exist for future research? }\end{array}$ \\
\hline $\begin{array}{l}\text { Risks and } \\
\text { opportunities }\end{array}$ & $\begin{array}{l}\text { Collate examples of non-state policing in fragile contexts, including evidence } \\
\text { of impact and risks. Look at Northern Ireland and the former Soviet Union, but } \\
\text { examples from further afield would also be of interest. }\end{array}$ \\
\hline How to improve & $\begin{array}{l}\text { What lessons or evidence is there from previous or ongoing efforts to establish } \\
\text { joint operating principles agreed by humanitarian actors to improve } \\
\text { humanitarian access and what factors contributed to their success or failure? }\end{array}$ \\
\hline
\end{tabular}

Source: Author's interpretation drawing on K4D data

\section{Forms of conflict, violence, and/or peace addressed by the reports}

Another way to analyse the reports is to look at the different forms of conflict, violence and/or peace that the reports focus on. This categorisation was carried out according to the research questions of the reports. Some reports were categorised as focussing on multiple forms and so are counted under more than one topic. Figure 9 lists the forms that the reports focussed on with examples. The most commonly used form is "conflict (general)", with 30 of 68 papers requesting this. The next most common categories are "peace-making/building" (14 out of 68 reports), "stability/instability" (12), and "violence (general)" (10). Some reports focus on more specific forms of conflict, violence and/or peace, e.g.: state violence (6 reports out of 68 ); GBV (6); extremism (6); resilience (5); and protest and unrest (4)

Figure 9: Forms of conflict, violence, and/or peace addressed in the reports

\begin{tabular}{|l|l|l|}
$\begin{array}{l}\text { Forms of conflict, } \\
\text { violence and/or } \\
\text { peace }\end{array}$ & $\begin{array}{l}\text { No. of } \\
\text { reports }\end{array}$ & \multicolumn{2}{l|}{$\begin{array}{l}\text { Example of research question/s } \\
\text { Conflict (general) }\end{array}$} & 30 & $\begin{array}{l}\text { What is the relationship between population growth and age } \\
\text { structure and conflict and governance in Sub-Saharan Africa? } \\
\text { What other factors interact with population growth and age } \\
\text { structure to affect conflict and governance in the region? What } \\
\text { are the implications for policy and programming responses? }\end{array}$ \\
\hline $\begin{array}{l}\text { Peace- } \\
\text { making/building }\end{array}$ & 14 & $\begin{array}{l}\text { What lessons are there on what works to promote accountability } \\
\text { and justice for communities in natural resource-based conflicts }\end{array}$ \\
\hline
\end{tabular}




\begin{tabular}{|c|c|c|}
\hline & & $\begin{array}{l}\text { in sub-Saharan Africa? How can security providers play a } \\
\text { positive role? }\end{array}$ \\
\hline Stability/Instability & 12 & $\begin{array}{l}\text { Please provide an overview of how health programmes can build } \\
\text { stability and promote peacebuilding? What the evidence tells us } \\
\text { about how health programmes can address drivers of conflict } \\
\text { and instability? }\end{array}$ \\
\hline Violence (general) & 10 & $\begin{array}{l}\text { Provide an up-to-date report based on available evidence that } \\
\text { includes: What has worked/hasn't worked in reducing and } \\
\text { preventing school-related violence, and in addressing school- } \\
\text { related violence when it happens? What measures have worked } \\
\text { best to promote safe, inclusive and violence-free schools? }\end{array}$ \\
\hline $\begin{array}{l}\text { Political violence } \\
\& \text { armed conflict }\end{array}$ & 10 & $\begin{array}{l}\text { What are the different groups involved in Extremist, Violent } \\
\text { Extremism and Terrorism in Yemen? }\end{array}$ \\
\hline Peace process & 7 & $\begin{array}{l}\text { What are the lessons learned on the role of conditionality } \\
\text { specifically in securing provisions protecting women's rights as } \\
\text { an outcome of a peace process? What other approaches can be } \\
\text { used by international development partners to ensure inclusion } \\
\text { of women's rights provisions? What lessons can be applied to } \\
\text { the Afghanistan peace process? }\end{array}$ \\
\hline State violence & 6 & $\begin{array}{l}\text { What interventions related to policing in fragile and conflict } \\
\text { affected states have caused harm to marginalised groups or } \\
\text { resulted in negative unintended consequences? }\end{array}$ \\
\hline GBV & 6 & $\begin{array}{l}\text { What evidence is there on what works and what doesn't work } \\
\text { when supporting survivors of sexual violence in conflict across } \\
\text { Asia, Africa and South America? }\end{array}$ \\
\hline Extremism & 6 & $\begin{array}{l}\text { What are the lessons learned from Preventing and Countering } \\
\text { Violent Extremism (P/CVE) programming implemented amid } \\
\text { ongoing conflict globally? Please focus on what has worked and } \\
\text { what were the challenges in delivering interventions addressing } \\
\text { "push" and "pull" factors. }\end{array}$ \\
\hline Resilience & 5 & $\begin{array}{l}\text { 1. What are the root causes and actors (national, international) } \\
\text { of conflict and instability in the North East of Kenya? } \\
\text { 2. What evidence tells about recent conflict dynamics in North } \\
\text { East of Kenya and how it interacts with those in Somalia? } \\
\text { 3. What sources of resilience can be identified in the literature } \\
\text { and what is the role of international actors engaging in the North } \\
\text { East of Kenya? } \\
\text { 4. Does literature identify credible scenarios for the political, } \\
\text { economic and conflict development in North East of Kenya? }\end{array}$ \\
\hline Protest \& unrest & 4 & $\begin{array}{l}\text { What economic interventions/tools supported by international } \\
\text { actors, including international financial institutions, have } \\
\text { delivered short term stability to manage popular unrest between } \\
\text { protestors and the state? }\end{array}$ \\
\hline
\end{tabular}




\begin{tabular}{|l|l|l|}
\hline $\begin{array}{l}\text { Mediation \& } \\
\text { negotiations }\end{array}$ & 4 & $\begin{array}{l}\text { What are the lessons learned on the role of aid conditionality in } \\
\text { inducing conflict parties to enter in to a peace process, and stay } \\
\text { at the table? }\end{array}$ \\
\hline $\begin{array}{l}\text { Interpersonal } \\
\text { violence }\end{array}$ & 3 & $\begin{array}{l}\text { What effects does violence in the home (either towards children } \\
\text { or between adults, such as intimate partner violence) have on } \\
\text { affected children's mental health and psychosocial wellbeing } \\
\text { during conflict? Identify the key evidence gaps on this topic. } \\
\text { Where possible, analyse how the situation differs for boys and } \\
\text { girls, as well as for children from different age groups. }\end{array}$ \\
\hline Social cohesion & 2 & $\begin{array}{l}\text { Based on the available literature, what lessons can be learned } \\
\text { from interventions on media/communications for development, } \\
\text { focused on peacebuilding/building social cohesion/changing } \\
\text { prevailing narratives on conflict? }\end{array}$ \\
\hline
\end{tabular}

Source: Author's interpretation drawing on K4D data

\section{Origin of research requests - FCDO Cadres and teams}

Figure 10 depicts the Cadres that have requested research on conflict from K4D. It reveals that while several FCDO Cadres submit research requests relating to conflict, the vast majority of these requests do indeed come from the conflict Cadre.

The second largest requesting group is "other", meaning the request was made from someone outside of FCDO (and before September 2020, from someone outside of DFID). The large number of requests from staff categorised as "other" may reflect the cross-departmental nature of conflict work beyond international development - certainly this can be seen in the requests that were issued by staff from the Stabilisation Unit that did not identify as sitting in DFID/FCDO.

Examples from the "other" category include a report on school-related violence that was requested by an HMG staffer seconded to the European Union. Other FCDO Cadres that have requested multiple conflict related reports in this sample include social development, humanitarian and governance. The dominance of these cadres (including conflict) broadly reflects the most frequent users of K4D in general (K4D, 2020).

Figure 10: No. of reports requested by FCDO Cadre 


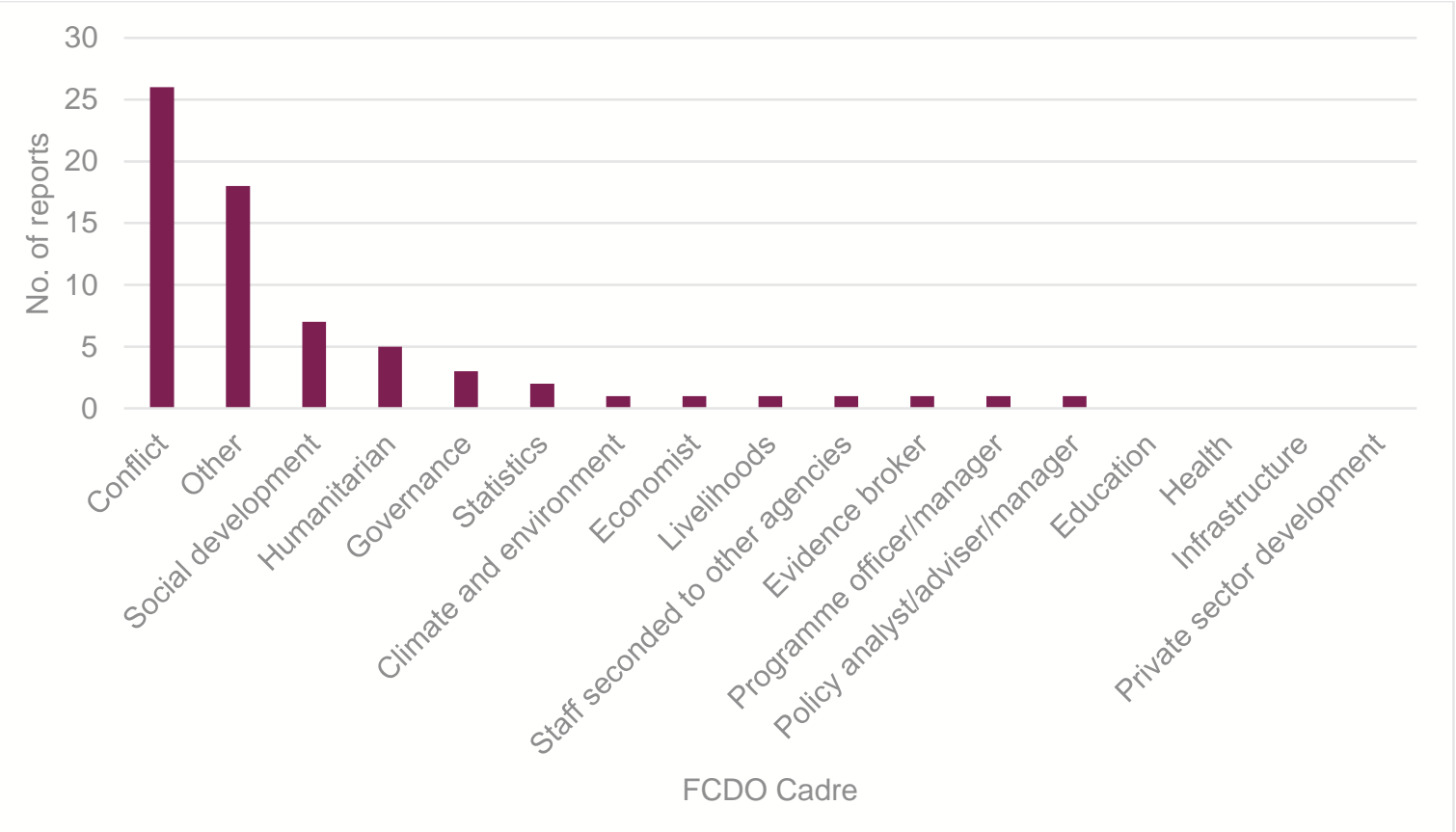

Source: Author's analysis drawing on K4D data

Research requests to K4D were spread pretty evenly over a large number of teams - 42 teams in total for the 68 reports in the sample. The top 6 requesting teams were: Stabilisation Unit 6 report requests out of 68); Afghanistan (4 requests), Yemen (4); Conflict, Security and Justice Group (3), Heads of Profession (3), and STAR MENA \& Asia team - Stabilisation Unit (3) (see Figure 11). Notably, comparability of the data is complicated by the variable use of team names e.g. some people refer to the "Stabilisation Unit" as a team, while others refer to "STAR MENA \& Asia team - Stabilisation Unit" as a team.

Figure 11: Most frequent conflict, violence, and/or peace related requests to K4D by FCDO teams (top 6 out of 42 teams in total) 


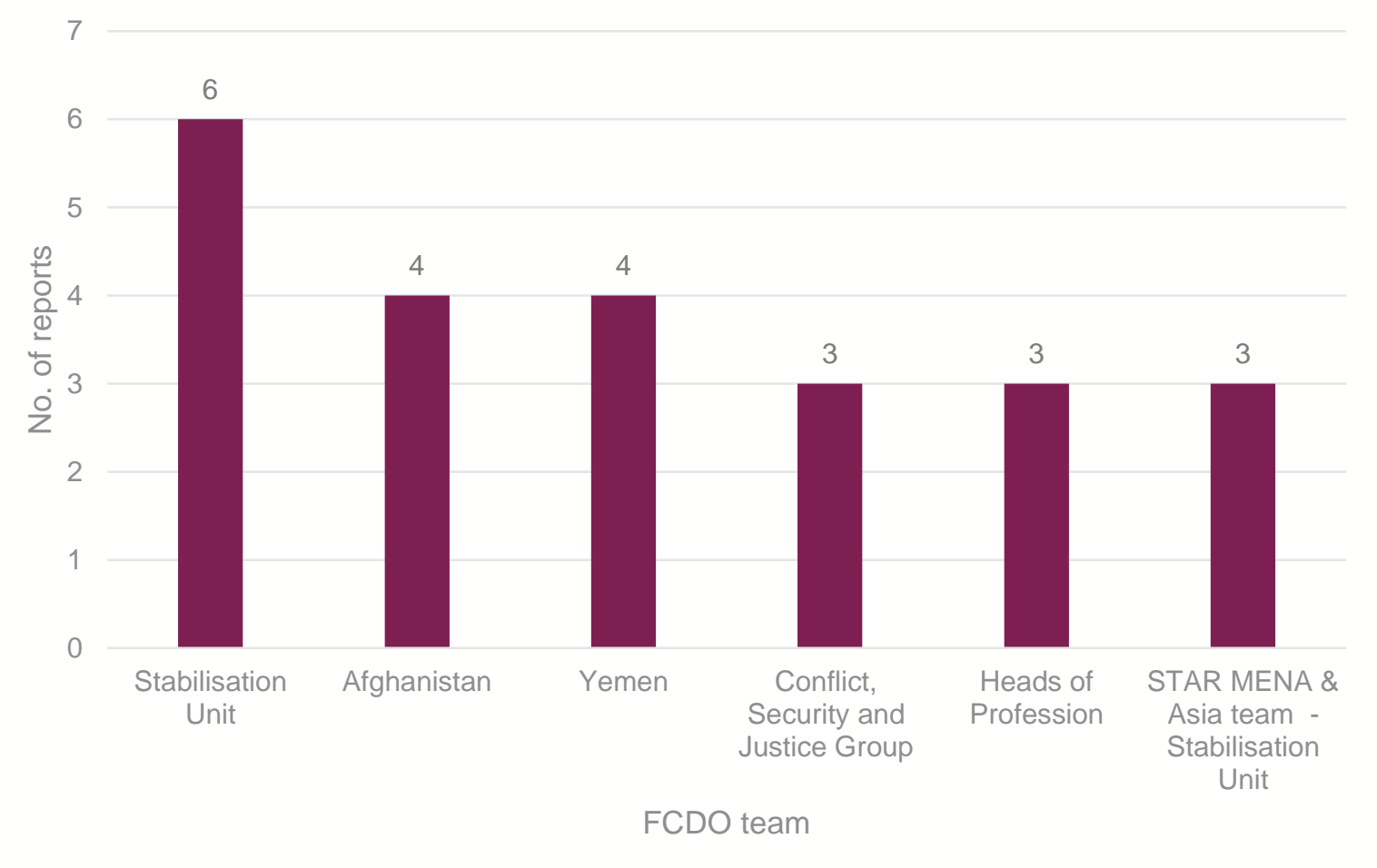

Source: Author's analysis drawing on K4D data

\section{Intended use of reports}

The biggest share of reports relating to conflict, violence, and/or peace were requested to inform programme design and/or to develop a business case for an intervention or programme (22 reports out of 68) (see Graphic X below). The other uses were: scoping/ syntheses of evidence (10); inform policy work (10); feed into larger piece of work (10); and support meeting/ event (2). 14 of the reports did not state a purpose.

Figure 12: Intended use of research 


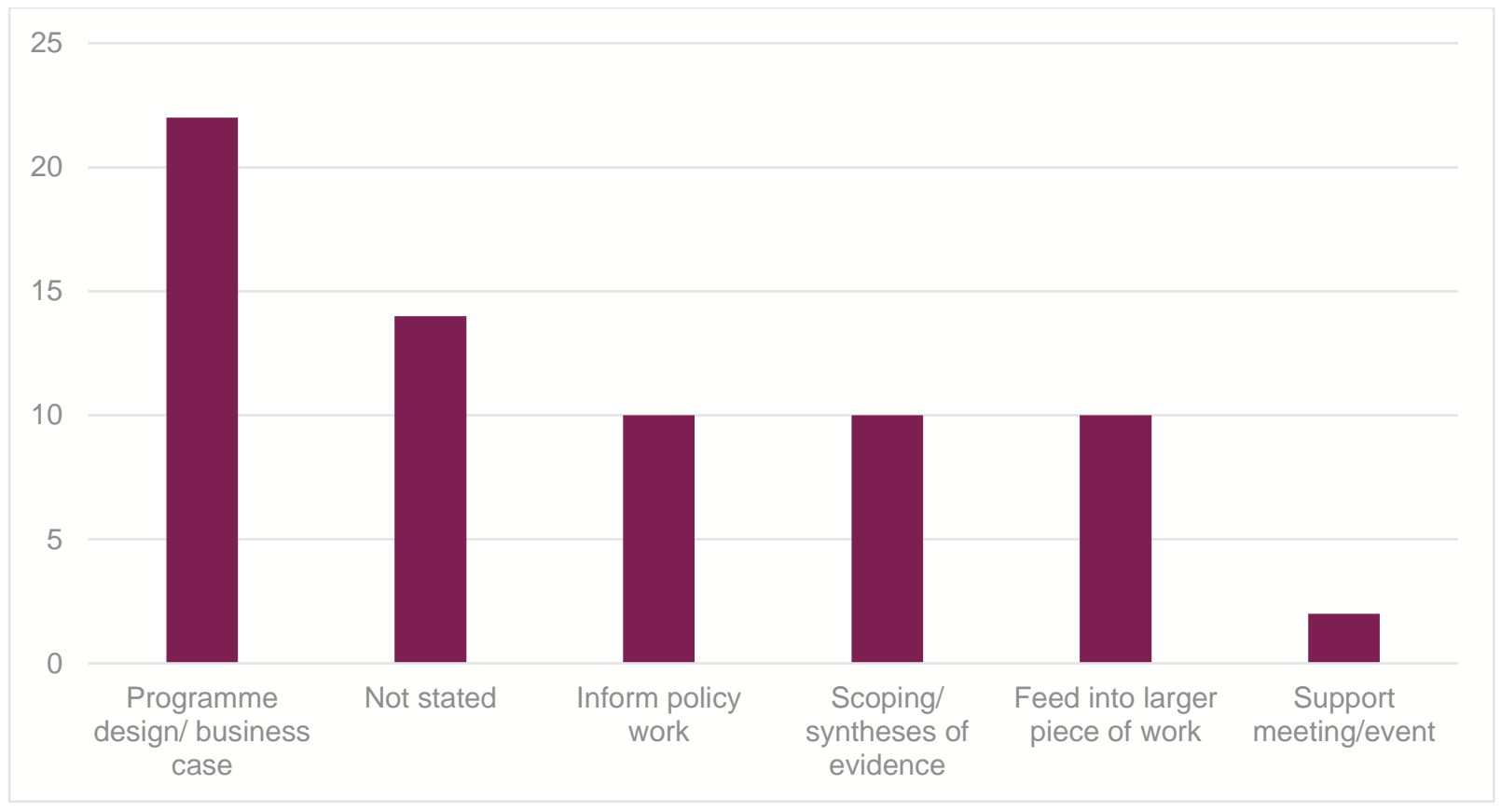

Source: Author's analysis drawing on K4D data

\section{Geography}

The geographical focus of this selection of reports is explored by categorising the reports according to the regions and countries mentioned in the research questions and report titles, and by using the World Bank regions ${ }^{7}$ as categories (see Figure 13). Some reports are categorised under multiple categories. Almost half of the requests (33) take a general focus, where no region or country is specifically mentioned. Following that, the most common regions of focus were: MENA (17 reports out of 68); and SSA (13 reports). These figures reflect MENA and SSA as the two regions experiencing most conflict since 2016 compared to other world regions. There are also a number of reports focussing on the other world regions: South Asia (8); Multi-region ${ }^{8}(6)$; Europe and Central Asia (5); East Asia and Pacific (4); and Latin America \& the Caribbean (4).

Figure 13: Regional geographic focus of the reports

\footnotetext{
7 Based on World Bank country groups: https://datahelpdesk.worldbank.org/knowledgebase/articles/906519world-bank-country-and-lending-groups

${ }^{8}$ Papers classified as "multi-region" focus on countries in two or more different world regions.
} 


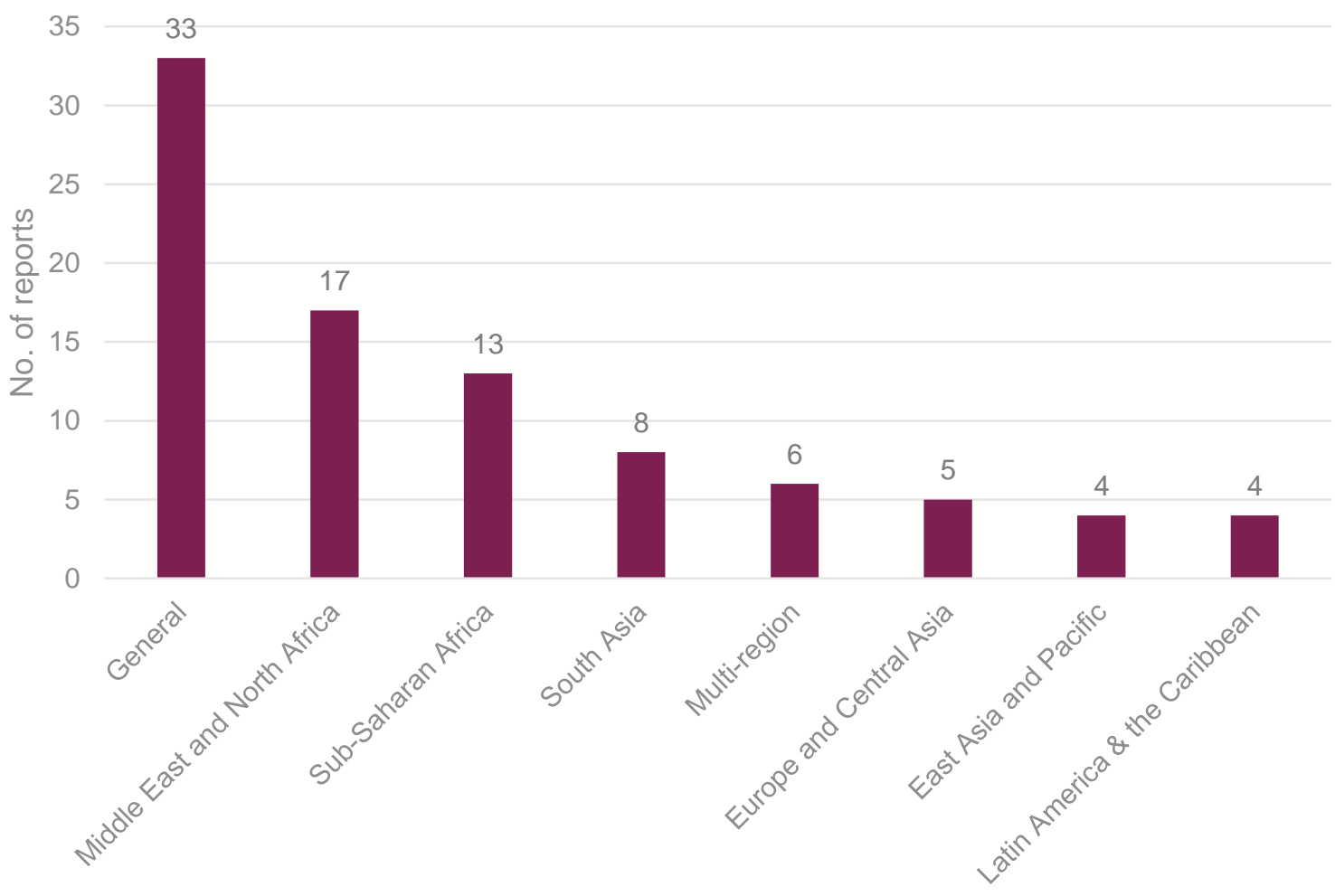

Regional geographic focus of the reports

Source: Author's analysis drawing on K4D data

The country-focus of the reports is also explored by categorising the countries that are mentioned in the title or research question/s of the reports. These are either countries of focus for the report, or suggested countries to draw lessons from. Some research questions mention multiple countries. As Figure 14 shows, these reports have a wide country coverage, with 38 countries mentioned in total, the majority of those (27 countries) are only mentioned once in one report. There are a few countries that are mentioned in multiple report requests: Afghanistan (4); Yemen (4); Sri Lanka (3); Kenya (2); South Sudan (2); Bangladesh (2); Nigeria (2); Somalia (2); Iraq (2); and Libya (2). This reflects some the countries most affected by conflict and fragility since 2016, and also the countries that are UK aid priorities. For example, although the Central African Republic and Chad have also been heavily affected by conflict and fragility since 2016 , they are not UK aid priorities (as individual countries) ${ }^{9}$ and therefore have garnered less interest from FCDO and do not appear in the below list.

Figure 14: Number of reports that focus on a country, or mention a country in the research question to draw lessons from

\begin{tabular}{|l|l|}
\hline Country & No. of reports \\
\hline Afghanistan & 4 \\
\hline Yemen & 4 \\
\hline
\end{tabular}

\footnotetext{
${ }^{9}$ Notably, these countries do receive some attention from DFID and now the FCDO through the relatively recent addition of a Sahel regional team
} 


\begin{tabular}{|c|c|}
\hline Sri Lanka & 3 \\
\hline Kenya & 2 \\
\hline South Sudan & 2 \\
\hline Bangladesh & 2 \\
\hline Nigeria & 2 \\
\hline Somalia & 2 \\
\hline Iraq & 2 \\
\hline Libya & 2 \\
\hline Mozambique & 1 \\
\hline Tanzania & 1 \\
\hline Pakistan & 1 \\
\hline India & 1 \\
\hline Nepal & 1 \\
\hline Thailand & 1 \\
\hline Vietnam & 1 \\
\hline The Philippines & 1 \\
\hline Peru & 1 \\
\hline Indonesia & 1 \\
\hline Ukraine & 1 \\
\hline Occupied Palestinian Territories & 1 \\
\hline Syria & 1 \\
\hline Bosnia and Herzegovina & 1 \\
\hline Uganda & 1 \\
\hline Jordan & 1 \\
\hline Tunisia & 1 \\
\hline Burma & 1 \\
\hline Antigua and Barbuda & 1 \\
\hline Belize & 1 \\
\hline Dominica & 1 \\
\hline Grenada & 1 \\
\hline Guyana & 1 \\
\hline Saint Lucia & 1 \\
\hline Saint Vincent & 1 \\
\hline
\end{tabular}




\begin{tabular}{|l|l|}
\hline The Grenadines & 1 \\
\hline Trinidad and Tobago & 1 \\
\hline Haiti & 1 \\
\hline
\end{tabular}

Source: Author's analysis drawing on K4D data

\section{Feedback}

Users of the K4D helpdesk service are asked to complete an online evaluation form for every report, which asks users to grade reports on overall quality, relevance and clarity. 262 evaluation forms have been completed on HDQs from 2016 until March 2021 (K4D, 2021).

The Helpdesk reports in this selection received relatively low feedback via the evaluation form ${ }^{10}$ (at 16\%) compared to the average response for K4D Helpdesk reports (at around 35\%). The formal evaluation allows for ranking of papers on a scale of Excellent, Very good, Good, Fair and Poor. The 11 responses ranked the papers very positively, as: excellent (6 out of 11 responses); very good (4 responses); and good (1) (see Figure 15).

\section{Figure 15: Feedback from FCDO enquirers}

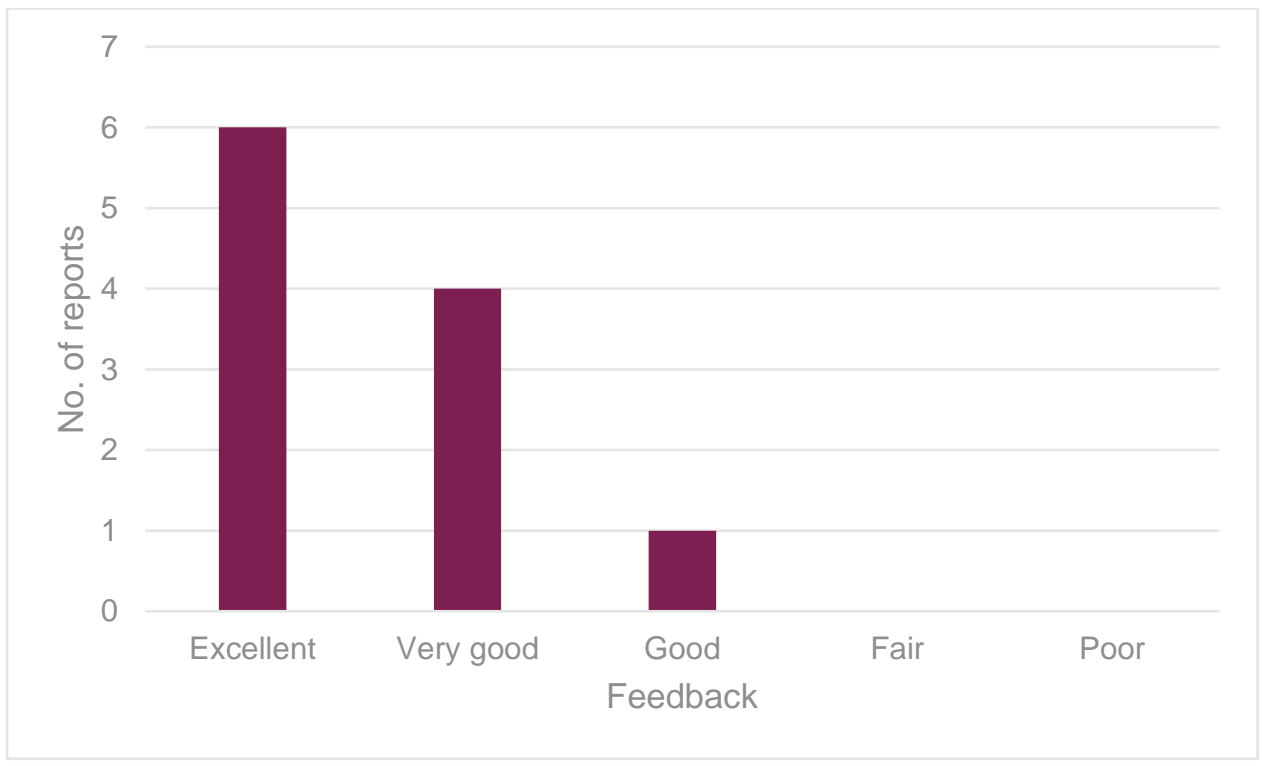

Source: Based on K4D data

\footnotetext{
${ }^{10}$ Overall informal feedback via email was more substantial, with $34 \%$ of the reports in this selection receiving
} informal feedback. All of those emails provided positive feedback. 


\section{Annex ${ }^{11}$}

Figure 16: List of papers included in this selection for analysis of K4D's work on conflict, violence, and peace (2016-2021)

\begin{tabular}{|c|c|c|c|c|c|c|c|}
\hline $\begin{array}{l}\text { Thematic } \\
\text { areas }\end{array}$ & Title & $\begin{array}{l}\text { Type of } \\
\text { report }\end{array}$ & $\begin{array}{l}\text { Request } \\
\text { type }\end{array}$ & $\begin{array}{l}\text { FCDO } \\
\text { intended } \\
\text { purpose }\end{array}$ & $\begin{array}{l}\text { Regional } \\
\text { scope }\end{array}$ & $\begin{array}{c}\text { Focus } \\
\text { countries }\end{array}$ & $\begin{array}{c}\text { Requester } \\
\text { Cadre }\end{array}$ \\
\hline Conflict & Current trends in violent conflict & $\begin{array}{l}\text { Single } \\
\mathrm{HDQ}\end{array}$ & $\begin{array}{l}\text { Context/ } \\
\text { conflict } \\
\text { analysis; } \\
\text { intervention } \\
\text { analysis }\end{array}$ & $\begin{array}{l}\text { Feed into } \\
\text { larger piece } \\
\text { of work }\end{array}$ & General & & Conflict \\
\hline Conflict & $\begin{array}{l}\text { Rural stakeholder engagement } \\
\text { in social cohesion, reconciliation } \\
\text { and peacebuilding projects }\end{array}$ & $\begin{array}{l}\text { Single } \\
\mathrm{HDQ}\end{array}$ & $\begin{array}{l}\text { Intervention } \\
\text { analysis }\end{array}$ & $\begin{array}{l}\text { Inform policy } \\
\text { work }\end{array}$ & General & & Other \\
\hline Conflict & $\begin{array}{l}\text { Lessons learned from } \\
\text { preventing and countering } \\
\text { violent extremism (P/CVE) } \\
\text { programmes amid ongoing } \\
\text { conflict }\end{array}$ & $\begin{array}{l}\text { Single } \\
\mathrm{HDQ}\end{array}$ & $\begin{array}{l}\text { Intervention } \\
\text { analysis }\end{array}$ & & General & & Conflict \\
\hline Conflict & & $\begin{array}{l}\text { Single } \\
\mathrm{HDQ}\end{array}$ & $\begin{array}{l}\text { Context/ } \\
\text { conflict } \\
\text { analysis }\end{array}$ & & $\begin{array}{l}\text { Middle East } \\
\text { and North } \\
\text { Africa }\end{array}$ & Iraq & Other \\
\hline
\end{tabular}

11 This list omits the titles for papers that have not been published. 


\begin{tabular}{|c|c|c|c|c|c|c|c|}
\hline Conflict & $\begin{array}{l}\text { Lessons from conflict resolution } \\
\text { interventions }\end{array}$ & $\begin{array}{l}\text { Single } \\
\mathrm{HDQ}\end{array}$ & $\begin{array}{l}\text { Intervention } \\
\text { analysis }\end{array}$ & $\begin{array}{l}\text { Inform policy } \\
\text { work }\end{array}$ & General & Nigeria & Conflict \\
\hline Conflict & $\begin{array}{l}\text { Narratives, ethnicity and post- } \\
\text { conflict divisions in Mostar }\end{array}$ & $\begin{array}{l}\text { Single } \\
\mathrm{HDQ}\end{array}$ & $\begin{array}{l}\text { Context/ } \\
\text { conflict } \\
\text { analysis }\end{array}$ & & $\begin{array}{l}\text { Europe and } \\
\text { Central Asia }\end{array}$ & $\begin{array}{l}\text { Bosnia and } \\
\text { Herzegovina }\end{array}$ & Other \\
\hline Conflict & & $\begin{array}{l}\text { Single } \\
\mathrm{HDQ}\end{array}$ & $\begin{array}{l}\text { Intervention } \\
\text { analysis }\end{array}$ & $\begin{array}{l}\text { Inform policy } \\
\text { work }\end{array}$ & $\begin{array}{l}\text { Multi-region; } \\
\text { Latin America \& } \\
\text { the Caribbean; } \\
\text { Middle East } \\
\text { and North } \\
\text { Africa; South } \\
\text { Asia; Sub- } \\
\text { Saharan Africa }\end{array}$ & $\begin{array}{l}\text { Afghanistan; } \\
\text { Sri Lanka; } \\
\text { Somalia; } \\
\text { Iraq; } \\
\text { Uganda; } \\
\text { Peru }\end{array}$ & $\begin{array}{l}\text { Social } \\
\text { Development }\end{array}$ \\
\hline Conflict & $\begin{array}{l}\text { the trends and developments } \\
\text { relating to border disputes and } \\
\text { micro-conflicts in South/South- } \\
\text { East Asia }\end{array}$ & $\begin{array}{l}\text { Single } \\
\mathrm{HDQ}\end{array}$ & $\begin{array}{l}\text { Context/ } \\
\text { conflict } \\
\text { analysis }\end{array}$ & $\begin{array}{l}\text { Support } \\
\text { meeting / } \\
\text { event }\end{array}$ & $\begin{array}{l}\text { East Asia and } \\
\text { Pacific; South } \\
\text { Asia; Sub- } \\
\text { Saharan Africa }\end{array}$ & & Conflict \\
\hline Conflict & $\begin{array}{l}\text { Coordinating support to peace } \\
\text { processes }\end{array}$ & $\begin{array}{l}\text { Single } \\
\mathrm{HDQ}\end{array}$ & $\begin{array}{l}\text { Intervention } \\
\text { analysis }\end{array}$ & $\begin{array}{l}\text { Feed into } \\
\text { larger piece } \\
\text { of work }\end{array}$ & General & & Conflict \\
\hline Conflict & $\begin{array}{l}\text { Non-State Policing in Fragile } \\
\text { Contexts }\end{array}$ & $\begin{array}{l}\text { Multi- } \\
\text { HDQ }\end{array}$ & $\begin{array}{l}\text { Intervention } \\
\text { analysis }\end{array}$ & $\begin{array}{l}\text { Scoping/ } \\
\text { syntheses of } \\
\text { evidence }\end{array}$ & $\begin{array}{l}\text { Europe and } \\
\text { Central Asia }\end{array}$ & & Other \\
\hline
\end{tabular}




\begin{tabular}{|c|c|c|c|c|c|c|c|}
\hline Conflict & Conflict analysis Yemen & $\begin{array}{l}\text { Multi- } \\
\text { HDQ }\end{array}$ & $\begin{array}{l}\text { Context/ } \\
\text { conflict } \\
\text { analysis }\end{array}$ & $\begin{array}{l}\text { Scoping/ } \\
\text { syntheses of } \\
\text { evidence }\end{array}$ & $\begin{array}{l}\text { Middle East } \\
\text { and North } \\
\text { Africa }\end{array}$ & Yemen & Conflict \\
\hline $\begin{array}{l}\text { Conflict; } \\
\text { Climate \& } \\
\text { Environment }\end{array}$ & $\begin{array}{l}\text { Climate change and stability in } \\
\text { North Africa }\end{array}$ & $\begin{array}{l}\text { Single } \\
\mathrm{HDQ}\end{array}$ & $\begin{array}{l}\text { Context/ } \\
\text { conflict } \\
\text { analysis }\end{array}$ & $\begin{array}{l}\text { Programme } \\
\text { design/ } \\
\text { business } \\
\text { case }\end{array}$ & $\begin{array}{l}\text { Middle East } \\
\text { and North } \\
\text { Africa }\end{array}$ & & $\begin{array}{l}\text { Programme } \\
\text { officer/manager }\end{array}$ \\
\hline $\begin{array}{l}\text { Conflict; } \\
\text { climate \& } \\
\text { environment }\end{array}$ & $\begin{array}{l}\text { Climate change as a driver of } \\
\text { conflict in Afghanistan and other } \\
\text { Fragile and Conflict Affected } \\
\text { States }\end{array}$ & $\begin{array}{l}\text { Single } \\
\mathrm{HDQ}\end{array}$ & $\begin{array}{l}\text { Context/ } \\
\text { conflict } \\
\text { analysis }\end{array}$ & $\begin{array}{l}\text { Scoping/ } \\
\text { syntheses of } \\
\text { evidence }\end{array}$ & $\begin{array}{l}\text { Middle East } \\
\text { and North } \\
\text { Africa }\end{array}$ & & $\begin{array}{l}\text { Policy } \\
\text { analyst/adviser/ } \\
\text { manager }\end{array}$ \\
\hline $\begin{array}{l}\text { Conflict; } \\
\text { climate \& } \\
\text { environment; } \\
\text { governance }\end{array}$ & & $\begin{array}{l}\text { Multi- } \\
\text { HDQ }\end{array}$ & $\begin{array}{l}\text { Context/ } \\
\text { conflict } \\
\text { analysis; } \\
\text { intervention } \\
\text { analysis }\end{array}$ & $\begin{array}{l}\text { Support } \\
\text { meeting / } \\
\text { event }\end{array}$ & General & & $\begin{array}{l}\text { Climate \& } \\
\text { Environment }\end{array}$ \\
\hline $\begin{array}{l}\text { Conflict; } \\
\text { Climate \& } \\
\text { Environment; } \\
\text { health; } \\
\text { economics }\end{array}$ & $\begin{array}{l}\text { Trends in conflict and stability in } \\
\text { the Indo-Pacific }\end{array}$ & EIR & $\begin{array}{l}\text { Context/ } \\
\text { conflict } \\
\text { analysis }\end{array}$ & $\begin{array}{l}\text { Programme } \\
\text { design/ } \\
\text { business } \\
\text { case }\end{array}$ & $\begin{array}{l}\text { Multi-region; } \\
\text { East Asia and } \\
\text { Pacific; South } \\
\text { Asia }\end{array}$ & $\begin{array}{l}\text { Pakistan; } \\
\text { India; Nepal; } \\
\text { Sri Lanka; } \\
\text { Bangladesh; } \\
\text { Thailand; } \\
\text { Burma }\end{array}$ & Conflict \\
\hline $\begin{array}{l}\text { Conflict; } \\
\text { economist }\end{array}$ & & $\begin{array}{l}\text { Single } \\
\mathrm{HDQ}\end{array}$ & $\begin{array}{l}\text { Context/ } \\
\text { conflict } \\
\text { analysis }\end{array}$ & $\begin{array}{l}\text { Inform policy } \\
\text { work }\end{array}$ & General & & Conflict \\
\hline
\end{tabular}




\begin{tabular}{|c|c|c|c|c|c|c|c|}
\hline $\begin{array}{l}\text { Conflict; } \\
\text { education; } \\
\text { social } \\
\text { development }\end{array}$ & School-related violence & $\begin{array}{l}\text { Single } \\
\mathrm{HDQ}\end{array}$ & $\begin{array}{l}\text { Intervention } \\
\text { analysis }\end{array}$ & $\begin{array}{l}\text { Feed into } \\
\text { larger piece } \\
\text { of work }\end{array}$ & $\begin{array}{l}\text { Multi-region; } \\
\text { East Asia and } \\
\text { Pacific; Latin } \\
\text { America \& the } \\
\text { Caribbean; } \\
\text { Middle East } \\
\text { and North } \\
\text { Africa; South } \\
\text { Asia; Sub- } \\
\text { Saharan Africa }\end{array}$ & & $\begin{array}{l}\text { Staff seconded } \\
\text { to other } \\
\text { agencies }\end{array}$ \\
\hline $\begin{array}{l}\text { Conflict; } \\
\text { education; } \\
\text { social } \\
\text { development }\end{array}$ & & $\begin{array}{l}\text { Single } \\
\mathrm{HDQ}\end{array}$ & $\begin{array}{l}\text { Context/ } \\
\text { conflict } \\
\text { analysis; } \\
\text { intervention } \\
\text { analysis }\end{array}$ & $\begin{array}{l}\text { Programme } \\
\text { design// } \\
\text { business } \\
\text { case }\end{array}$ & General & & Conflict \\
\hline $\begin{array}{l}\text { Conflict; } \\
\text { governance }\end{array}$ & $\begin{array}{l}\text { Conflict analysis of North } \\
\text { Eastern Kenya }\end{array}$ & EIR & $\begin{array}{l}\text { Context/ } \\
\text { conflict } \\
\text { analysis }\end{array}$ & $\begin{array}{l}\text { Inform policy } \\
\text { work }\end{array}$ & $\begin{array}{l}\text { Sub-Saharan } \\
\text { Africa }\end{array}$ & Kenya & Conflict \\
\hline $\begin{array}{l}\text { Conflict; } \\
\text { governance }\end{array}$ & $\begin{array}{l}\text { Conditionality and other } \\
\text { approaches to secure women's } \\
\text { rights provisions in peace } \\
\text { processes }\end{array}$ & $\begin{array}{l}\text { Single } \\
\mathrm{HDQ}\end{array}$ & $\begin{array}{l}\text { Intervention } \\
\text { analysis }\end{array}$ & & $\begin{array}{l}\text { Middle East } \\
\text { and North } \\
\text { Africa }\end{array}$ & Afghanistan & Conflict \\
\hline $\begin{array}{l}\text { Conflict; } \\
\text { governance }\end{array}$ & $\begin{array}{l}\text { International Actors' Support on } \\
\text { Inclusive Peace Processes }\end{array}$ & $\begin{array}{l}\text { Single } \\
\mathrm{HDQ}\end{array}$ & $\begin{array}{l}\text { Intervention } \\
\text { analysis }\end{array}$ & $\begin{array}{l}\text { Programme } \\
\text { design/ } \\
\text { business } \\
\text { case }\end{array}$ & General & & Other \\
\hline
\end{tabular}




\begin{tabular}{|c|c|c|c|c|c|c|c|}
\hline $\begin{array}{l}\text { Conflict; } \\
\text { governance }\end{array}$ & & $\begin{array}{l}\text { Multi- } \\
\text { HDQ }\end{array}$ & $\begin{array}{l}\text { Context/ } \\
\text { conflict } \\
\text { analysis }\end{array}$ & $\begin{array}{l}\text { Programme } \\
\text { design/ } \\
\text { business } \\
\text { case }\end{array}$ & $\begin{array}{l}\text { Latin America \& } \\
\text { the Caribbean }\end{array}$ & $\begin{array}{l}\text { Antigua and } \\
\text { Barbuda, } \\
\text { Belize, } \\
\text { Dominica, } \\
\text { Grenada, } \\
\text { Guyana, } \\
\text { Saint Lucia, } \\
\text { Saint } \\
\text { Vincent, the } \\
\text { Grenadines, } \\
\text { Trinidad and } \\
\text { Tobago, } \\
\text { Haiti }\end{array}$ & Governance \\
\hline $\begin{array}{l}\text { Conflict; } \\
\text { governance }\end{array}$ & $\begin{array}{l}\text { The role of aid conditionality in } \\
\text { inducing conflict parties to enter } \\
\text { in to a peace process }\end{array}$ & $\begin{array}{l}\text { Single } \\
\mathrm{HDQ}\end{array}$ & $\begin{array}{l}\text { Intervention } \\
\text { analysis }\end{array}$ & & General & & Conflict \\
\hline $\begin{array}{l}\text { Conflict; } \\
\text { governance }\end{array}$ & Conflict analysis of Bangladesh & $\begin{array}{l}\text { Multi- } \\
\text { HDQ }\end{array}$ & $\begin{array}{l}\text { Context/ } \\
\text { conflict } \\
\text { analysis }\end{array}$ & $\begin{array}{l}\text { Programme } \\
\text { design/ } \\
\text { business } \\
\text { case }\end{array}$ & South Asia & Bangladesh & Conflict \\
\hline $\begin{array}{l}\text { Conflict; } \\
\text { governance }\end{array}$ & & $\begin{array}{l}\text { Multi- } \\
\text { HDQ }\end{array}$ & $\begin{array}{l}\text { Context/ } \\
\text { conflict } \\
\text { analysis; } \\
\text { intervention } \\
\text { analysis }\end{array}$ & & South Asia & Sri Lanka & Other \\
\hline $\begin{array}{l}\text { Conflict; } \\
\text { governance }\end{array}$ & $\begin{array}{l}\text { Implementation of Security } \\
\text { Council resolution } 1325 \text { in Libya }\end{array}$ & $\begin{array}{l}\text { Single } \\
\mathrm{HDQ}\end{array}$ & $\begin{array}{l}\text { Intervention } \\
\text { analysis }\end{array}$ & $\begin{array}{l}\text { Programme } \\
\text { design/ }\end{array}$ & General & Libya & Conflict \\
\hline
\end{tabular}




\begin{tabular}{|c|c|c|c|c|c|c|c|}
\hline & & & & $\begin{array}{l}\text { business } \\
\text { case }\end{array}$ & & & \\
\hline $\begin{array}{l}\text { Conflict; } \\
\text { governance; } \\
\text { social } \\
\text { development }\end{array}$ & $\begin{array}{l}\text { the relationship between } \\
\text { population growth and age } \\
\text { structure and conflict and } \\
\text { governance in Sub-Saharan } \\
\text { Africa }\end{array}$ & EIR & $\begin{array}{l}\text { Context/ } \\
\text { conflict } \\
\text { analysis }\end{array}$ & $\begin{array}{l}\text { Inform policy } \\
\text { work }\end{array}$ & $\begin{array}{l}\text { Sub-Saharan } \\
\text { Africa }\end{array}$ & & Other \\
\hline $\begin{array}{l}\text { Conflict; } \\
\text { health }\end{array}$ & $\begin{array}{l}\text { COVID-19 in Eastern Africa: } \\
\text { impact analysis on conflict and } \\
\text { security }\end{array}$ & $\begin{array}{l}\text { Multi- } \\
\text { HDQ }\end{array}$ & $\begin{array}{l}\text { Context/ } \\
\text { conflict } \\
\text { analysis }\end{array}$ & $\begin{array}{l}\text { Programme } \\
\text { design/ } \\
\text { business } \\
\text { case }\end{array}$ & $\begin{array}{l}\text { Sub-Saharan } \\
\text { Africa }\end{array}$ & & Other \\
\hline $\begin{array}{l}\text { Conflict; } \\
\text { health }\end{array}$ & $\begin{array}{l}\text { Health programmes and } \\
\text { peacebuilding in FCAS }\end{array}$ & $\begin{array}{l}\text { Single } \\
\text { HDQ }\end{array}$ & $\begin{array}{l}\text { Intervention } \\
\text { analysis }\end{array}$ & $\begin{array}{l}\text { Programme } \\
\text { design/ } \\
\text { business } \\
\text { case }\end{array}$ & General & & Conflict \\
\hline $\begin{array}{l}\text { Conflict; } \\
\text { livelihoods }\end{array}$ & $\begin{array}{l}\text { Livestock and conflict in South } \\
\text { Sudan }\end{array}$ & $\begin{array}{l}\text { Multi- } \\
\text { HDQ }\end{array}$ & $\begin{array}{l}\text { Context/ } \\
\text { conflict } \\
\text { analysis }\end{array}$ & & $\begin{array}{l}\text { Sub-Saharan } \\
\text { Africa }\end{array}$ & $\begin{array}{l}\text { South } \\
\text { Sudan }\end{array}$ & Economics \\
\hline $\begin{array}{l}\text { Conflict; } \\
\text { livelihoods }\end{array}$ & $\begin{array}{l}\text { War Economy in North East } \\
\text { Nigeria }\end{array}$ & $\begin{array}{l}\text { Single } \\
\mathrm{HDQ}\end{array}$ & $\begin{array}{l}\text { Context/ } \\
\text { conflict } \\
\text { analysis }\end{array}$ & $\begin{array}{l}\text { Programme } \\
\text { design/ } \\
\text { business } \\
\text { case }\end{array}$ & $\begin{array}{l}\text { Sub-Saharan } \\
\text { Africa }\end{array}$ & Nigeria & Other \\
\hline $\begin{array}{l}\text { Conflict; } \\
\text { livelihoods; } \\
\text { governance }\end{array}$ & $\begin{array}{l}\text { Peacebuilding and extractives in } \\
\text { fragile and conflict-affected } \\
\text { states }\end{array}$ & $\begin{array}{l}\text { Multi- } \\
\text { HDQ }\end{array}$ & $\begin{array}{l}\text { Intervention } \\
\text { analysis }\end{array}$ & $\begin{array}{l}\text { Feed into } \\
\text { larger piece } \\
\text { of work }\end{array}$ & General & & Conflict \\
\hline
\end{tabular}




\begin{tabular}{|c|c|c|c|c|c|c|c|}
\hline $\begin{array}{l}\text { Conflict; } \\
\text { social } \\
\text { development }\end{array}$ & $\begin{array}{l}\text { Gender and countering violent } \\
\text { extremism (CVE) in the Kenya- } \\
\text { Mozambique region }\end{array}$ & $\begin{array}{l}\text { Multi- } \\
\text { HDQ }\end{array}$ & $\begin{array}{l}\text { Context/ } \\
\text { conflict } \\
\text { analysis; } \\
\text { intervention } \\
\text { analysis }\end{array}$ & $\begin{array}{l}\text { Programme } \\
\text { design/ } \\
\text { business } \\
\text { case }\end{array}$ & $\begin{array}{l}\text { Sub-Saharan } \\
\text { Africa }\end{array}$ & $\begin{array}{l}\text { Kenya, } \\
\text { Mozambiqu } \\
\text { e, Tanzania }\end{array}$ & Other \\
\hline $\begin{array}{l}\text { Conflict; } \\
\text { social } \\
\text { development }\end{array}$ & $\begin{array}{l}\text { Policing and marginalised } \\
\text { groups }\end{array}$ & $\begin{array}{l}\text { Multi- } \\
\text { HDQ }\end{array}$ & $\begin{array}{l}\text { Intervention } \\
\text { analysis }\end{array}$ & $\begin{array}{l}\text { Scoping/ } \\
\text { syntheses of } \\
\text { evidence }\end{array}$ & General & & $\begin{array}{l}\text { Social } \\
\text { Development }\end{array}$ \\
\hline $\begin{array}{l}\text { Conflict; } \\
\text { social } \\
\text { development }\end{array}$ & $\begin{array}{l}\text { Media/communications on } \\
\text { peacebuilding/building social } \\
\text { cohesion/changing prevailing } \\
\text { narratives on conflict; }\end{array}$ & $\begin{array}{l}\text { Single } \\
\mathrm{HDQ}\end{array}$ & $\begin{array}{l}\text { Intervention } \\
\text { analysis }\end{array}$ & $\begin{array}{l}\text { Programme } \\
\text { design/ } \\
\text { business } \\
\text { case }\end{array}$ & General & & Conflict \\
\hline $\begin{array}{l}\text { Conflict; } \\
\text { social } \\
\text { development }\end{array}$ & & $\begin{array}{l}\text { Single } \\
\text { HDQ }\end{array}$ & $\begin{array}{l}\text { Context/ } \\
\text { conflict } \\
\text { analysis }\end{array}$ & $\begin{array}{l}\text { Scoping/ } \\
\text { syntheses of } \\
\text { evidence }\end{array}$ & $\begin{array}{l}\text { Middle East } \\
\text { and North } \\
\text { Africa }\end{array}$ & $\begin{array}{l}\text { Occupied } \\
\text { Palestinian } \\
\text { Territories }\end{array}$ & Conflict \\
\hline $\begin{array}{l}\text { Conflict; } \\
\text { social } \\
\text { development }\end{array}$ & & $\begin{array}{l}\text { Multi- } \\
\text { HDQ }\end{array}$ & $\begin{array}{l}\text { Context/ } \\
\text { conflict } \\
\text { analysis }\end{array}$ & $\begin{array}{l}\text { Scoping/ } \\
\text { syntheses of } \\
\text { evidence }\end{array}$ & $\begin{array}{l}\text { Middle East } \\
\text { and North } \\
\text { Africa }\end{array}$ & Tunisia & Conflict \\
\hline $\begin{array}{l}\text { Conflict; } \\
\text { social } \\
\text { development; } \\
\text { health }\end{array}$ & & $\begin{array}{l}\text { Multi- } \\
\text { HDQ }\end{array}$ & $\begin{array}{l}\text { Context/ } \\
\text { conflict } \\
\text { analysis; } \\
\text { intervention } \\
\text { analysis }\end{array}$ & $\begin{array}{l}\text { Feed into } \\
\text { larger piece } \\
\text { of work }\end{array}$ & $\begin{array}{l}\text { Middle East } \\
\text { and North } \\
\text { Africa }\end{array}$ & Jordan & Conflict \\
\hline
\end{tabular}




\begin{tabular}{|c|c|c|c|c|c|c|}
\hline $\begin{array}{l}\text { Economist; } \\
\text { conflict }\end{array}$ & & $\begin{array}{l}\text { Single } \\
\mathrm{HDQ}\end{array}$ & $\begin{array}{l}\text { Context/ } \\
\text { conflict } \\
\text { analysis }\end{array}$ & & General & Conflict \\
\hline Education & $\begin{array}{l}\text { Violence in schools - annotated } \\
\text { bibliography }\end{array}$ & $\begin{array}{l}\text { Multi- } \\
\text { HDQ }\end{array}$ & $\begin{array}{l}\text { Context/ } \\
\text { conflict } \\
\text { analysis }\end{array}$ & $\begin{array}{l}\text { Programme } \\
\text { design// } \\
\text { business } \\
\text { case }\end{array}$ & General & $\begin{array}{l}\text { Evidence } \\
\text { broker }\end{array}$ \\
\hline $\begin{array}{l}\text { Education; } \\
\text { conflict }\end{array}$ & & EIR & $\begin{array}{l}\text { Context/ } \\
\text { conflict } \\
\text { analysis }\end{array}$ & & General & Conflict \\
\hline Governance & $\begin{array}{l}\text { Scalability of transitional justice } \\
\text { and reconciliation interventions } \\
\text { moving toward wider socio- } \\
\text { political change }\end{array}$ & $\begin{array}{l}\text { Multi- } \\
\text { HDQ }\end{array}$ & $\begin{array}{l}\text { Intervention } \\
\text { analysis }\end{array}$ & $\begin{array}{l}\text { Programme } \\
\text { design// } \\
\text { business } \\
\text { case }\end{array}$ & $\begin{array}{l}\text { Europe and } \\
\text { Central Asia }\end{array}$ & Conflict \\
\hline $\begin{array}{l}\text { Governance; } \\
\text { conflict }\end{array}$ & & $\begin{array}{l}\text { Single } \\
\mathrm{HDQ}\end{array}$ & $\begin{array}{l}\text { Context/ } \\
\text { conflict } \\
\text { analysis; } \\
\text { intervention } \\
\text { analysis }\end{array}$ & $\begin{array}{l}\text { Feed into } \\
\text { larger piece } \\
\text { of work }\end{array}$ & General & Governance \\
\hline $\begin{array}{l}\text { Governance; } \\
\text { conflict }\end{array}$ & $\begin{array}{l}\text { Transitional justice and } \\
\text { reconciliation in the Western } \\
\text { Balkans: approaches, impacts } \\
\text { and challenges }\end{array}$ & $\begin{array}{l}\text { Multi- } \\
\text { HDQ }\end{array}$ & $\begin{array}{l}\text { Intervention } \\
\text { analysis }\end{array}$ & $\begin{array}{l}\text { Programme } \\
\text { design// } \\
\text { business } \\
\text { case }\end{array}$ & $\begin{array}{l}\text { Europe and } \\
\text { Central Asia }\end{array}$ & Conflict \\
\hline
\end{tabular}




\begin{tabular}{|c|c|c|c|c|c|c|c|}
\hline $\begin{array}{l}\text { Governance; } \\
\text { conflict }\end{array}$ & $\begin{array}{l}\text { Maintaining basic state functions } \\
\text { and service delivery during } \\
\text { escalating crises }\end{array}$ & $\begin{array}{l}\text { Single } \\
\mathrm{HDQ}\end{array}$ & $\begin{array}{l}\text { Intervention } \\
\text { analysis }\end{array}$ & $\begin{array}{l}\text { Feed into } \\
\text { larger piece } \\
\text { of work }\end{array}$ & $\begin{array}{l}\text { Multi-region; } \\
\text { Middle East } \\
\text { and North } \\
\text { Africa; Sub- } \\
\text { Saharan Africa }\end{array}$ & $\begin{array}{l}\text { Afghanistan; } \\
\text { Somalia; } \\
\text { Syria; } \\
\text { Yemen }\end{array}$ & Statistics \\
\hline $\begin{array}{l}\text { Governance; } \\
\text { conflict }\end{array}$ & $\begin{array}{l}\text { ODA and non-ODA resources in } \\
\text { combination to address violent } \\
\text { conflict }\end{array}$ & $\begin{array}{l}\text { Single } \\
\mathrm{HDQ}\end{array}$ & $\begin{array}{l}\text { Intervention } \\
\text { analysis }\end{array}$ & & General & & Conflict \\
\hline $\begin{array}{l}\text { Governance; } \\
\text { conflict }\end{array}$ & $\begin{array}{l}\text { Responding to popular protests } \\
\text { in the MENA region }\end{array}$ & $\begin{array}{l}\text { Multi- } \\
\text { HDQ }\end{array}$ & $\begin{array}{l}\text { Intervention } \\
\text { analysis }\end{array}$ & $\begin{array}{l}\text { Feed into } \\
\text { larger piece } \\
\text { of work }\end{array}$ & $\begin{array}{l}\text { Middle East } \\
\text { and North } \\
\text { Africa }\end{array}$ & & Other \\
\hline $\begin{array}{l}\text { Health; social } \\
\text { development; } \\
\text { humanitarian }\end{array}$ & $\begin{array}{l}\text { Implications of not addressing } \\
\text { mental health and psychosocial } \\
\text { support (MHPSS) needs in } \\
\text { conflict situations }\end{array}$ & $\begin{array}{l}\text { Single } \\
\mathrm{HDQ}\end{array}$ & $\begin{array}{l}\text { Context/ } \\
\text { conflict } \\
\text { analysis }\end{array}$ & $\begin{array}{l}\text { Inform policy } \\
\text { work }\end{array}$ & General & & $\begin{array}{l}\text { Social } \\
\text { Development }\end{array}$ \\
\hline Humanitarian & $\begin{array}{l}\text { Joint operating principles among } \\
\text { humanitarian actors to improve } \\
\text { access }\end{array}$ & $\begin{array}{l}\text { Multi- } \\
\text { HDQ }\end{array}$ & $\begin{array}{l}\text { Intervention } \\
\text { analysis }\end{array}$ & $\begin{array}{l}\text { Programme } \\
\text { design// } \\
\text { business } \\
\text { case }\end{array}$ & General & & Humanitarian \\
\hline $\begin{array}{l}\text { Humanitarian; } \\
\text { conflict }\end{array}$ & $\begin{array}{l}\text { Humanitarian Protection of } \\
\text { persons affected by conflict - } \\
\text { Evidence mapping }\end{array}$ & $\begin{array}{l}\text { Single } \\
\mathrm{HDQ}\end{array}$ & $\begin{array}{l}\text { Intervention } \\
\text { analysis }\end{array}$ & $\begin{array}{l}\text { Feed into } \\
\text { larger piece } \\
\text { of work }\end{array}$ & General & & Humanitarian \\
\hline $\begin{array}{l}\text { Humanitarian; } \\
\text { conflict }\end{array}$ & $\begin{array}{l}\text { Evidence on measures to } \\
\text { address security in camp } \\
\text { settings }\end{array}$ & $\begin{array}{l}\text { Single } \\
\mathrm{HDQ}\end{array}$ & $\begin{array}{l}\text { Intervention } \\
\text { analysis }\end{array}$ & $\begin{array}{l}\text { Inform policy } \\
\text { work }\end{array}$ & General & & Humanitarian \\
\hline
\end{tabular}




\begin{tabular}{|c|c|c|c|c|c|c|c|}
\hline $\begin{array}{l}\text { Humanitarian; } \\
\text { conflict; } \\
\text { governance }\end{array}$ & $\begin{array}{l}\text { Humanitarian pauses and } \\
\text { corridors in contexts of conflict }\end{array}$ & $\begin{array}{l}\text { Multi- } \\
\text { HDQ }\end{array}$ & $\begin{array}{l}\text { Intervention } \\
\text { analysis }\end{array}$ & $\begin{array}{l}\text { Inform policy } \\
\text { work }\end{array}$ & General & & Humanitarian \\
\hline $\begin{array}{l}\text { Humanitarian; } \\
\text { conflict; } \\
\text { governance }\end{array}$ & & EIR & $\begin{array}{l}\text { Intervention } \\
\text { analysis }\end{array}$ & $\begin{array}{l}\text { Scoping/ } \\
\text { syntheses of } \\
\text { evidence }\end{array}$ & General & & Humanitarian \\
\hline $\begin{array}{l}\text { Livelihoods; } \\
\text { conflict }\end{array}$ & $\begin{array}{l}\text { Supporting and rebuilding } \\
\text { agriculture in protracted crises }\end{array}$ & $\begin{array}{l}\text { Single } \\
\mathrm{HDQ}\end{array}$ & $\begin{array}{l}\text { Intervention } \\
\text { analysis }\end{array}$ & $\begin{array}{l}\text { Programme } \\
\text { design/ } \\
\text { business } \\
\text { case }\end{array}$ & General & & Other \\
\hline $\begin{array}{l}\text { Livelihoods; } \\
\text { conflict; social } \\
\text { development }\end{array}$ & $\begin{array}{l}\text { Impact of conflict on youth in } \\
\text { South Sudan }\end{array}$ & $\begin{array}{l}\text { Multi- } \\
\text { HDQ }\end{array}$ & $\begin{array}{l}\text { Context/ } \\
\text { conflict } \\
\text { analysis }\end{array}$ & & $\begin{array}{l}\text { Sub-Saharan } \\
\text { Africa }\end{array}$ & $\begin{array}{l}\text { South } \\
\text { Sudan }\end{array}$ & Livelihoods \\
\hline $\begin{array}{l}\text { Livelihoods; } \\
\text { humanitarian; } \\
\text { social } \\
\text { development }\end{array}$ & $\begin{array}{l}\text { Cash transfers and cash plus } \\
\text { interventions in Yemen since } \\
\text { 2015: An annotated bibliography }\end{array}$ & $\begin{array}{l}\text { Single } \\
\mathrm{HDQ}\end{array}$ & $\begin{array}{l}\text { Intervention } \\
\text { analysis }\end{array}$ & $\begin{array}{l}\text { Scoping/ } \\
\text { syntheses of } \\
\text { evidence }\end{array}$ & $\begin{array}{l}\text { Middle East } \\
\text { and North } \\
\text { Africa }\end{array}$ & Yemen & Statistics \\
\hline $\begin{array}{l}\text { Private } \\
\text { sector; } \\
\text { conflict; } \\
\text { economics }\end{array}$ & $\begin{array}{l}\text { Economic interventions to } \\
\text { manage popular unrest }\end{array}$ & $\begin{array}{l}\text { Single } \\
\mathrm{HDQ}\end{array}$ & $\begin{array}{l}\text { Intervention } \\
\text { analysis }\end{array}$ & $\begin{array}{l}\text { Programme } \\
\text { design/ } \\
\text { business } \\
\text { case }\end{array}$ & General & & Other \\
\hline $\begin{array}{l}\text { Social } \\
\text { development }\end{array}$ & $\begin{array}{l}\text { Gender-sensitive security and } \\
\text { justice interventions in Sub- } \\
\text { Saharan Africa, MENA and } \\
\text { South Asia }\end{array}$ & $\begin{array}{l}\text { Single } \\
\mathrm{HDQ}\end{array}$ & $\begin{array}{l}\text { Intervention } \\
\text { analysis }\end{array}$ & & $\begin{array}{l}\text { Multi-region; } \\
\text { Middle East } \\
\text { and North } \\
\text { Africa; South }\end{array}$ & & Other \\
\hline
\end{tabular}




\begin{tabular}{|c|c|c|c|c|c|c|}
\hline & & & & & $\begin{array}{l}\text { Asia; Sub- } \\
\text { Saharan Africa }\end{array}$ & \\
\hline $\begin{array}{l}\text { Social } \\
\text { development; } \\
\text { conflict }\end{array}$ & $\begin{array}{l}\text { Supporting survivors of sexual } \\
\text { violence in conflict across Asia, } \\
\text { Africa and South America }\end{array}$ & $\begin{array}{l}\text { Single } \\
\mathrm{HDQ}\end{array}$ & $\begin{array}{l}\text { Intervention } \\
\text { analysis }\end{array}$ & $\begin{array}{l}\text { Programme } \\
\text { design/ } \\
\text { business } \\
\text { case }\end{array}$ & $\begin{array}{l}\text { Multi-region; } \\
\text { East Asia and } \\
\text { Pacific; Latin } \\
\text { America \& the } \\
\text { Caribbean; } \\
\text { Middle East } \\
\text { and North } \\
\text { Africa; South } \\
\text { Asia; Sub- } \\
\text { Saharan Africa }\end{array}$ & Other \\
\hline $\begin{array}{l}\text { Social } \\
\text { development; } \\
\text { conflict }\end{array}$ & $\begin{array}{l}\text { Lessons learned in promoting } \\
\text { accountability and resolution of } \\
\text { natural resource-based conflicts } \\
\text { in Africa }\end{array}$ & $\begin{array}{l}\text { Single } \\
\text { HDQ }\end{array}$ & $\begin{array}{l}\text { Intervention } \\
\text { analysis }\end{array}$ & & $\begin{array}{l}\text { Sub-Saharan } \\
\text { Africa }\end{array}$ & Conflict \\
\hline $\begin{array}{l}\text { Social } \\
\text { development; } \\
\text { conflict }\end{array}$ & $\begin{array}{l}\text { Risks faced by women and girls } \\
\text { with disabilities in conflict and } \\
\text { crises }\end{array}$ & $\begin{array}{l}\text { Single } \\
\mathrm{HDQ}\end{array}$ & $\begin{array}{l}\text { Context/ } \\
\text { conflict } \\
\text { analysis; } \\
\text { intervention } \\
\text { analysis }\end{array}$ & $\begin{array}{l}\text { Feed into } \\
\text { larger piece } \\
\text { of work }\end{array}$ & General & $\begin{array}{l}\text { Social } \\
\text { Development }\end{array}$ \\
\hline $\begin{array}{l}\text { Social } \\
\text { development; } \\
\text { conflict }\end{array}$ & $\begin{array}{l}\text { Transparency and accountability } \\
\text { in fragile states }\end{array}$ & $\begin{array}{l}\text { Single } \\
\mathrm{HDQ}\end{array}$ & $\begin{array}{l}\text { Intervention } \\
\text { analysis }\end{array}$ & $\begin{array}{l}\text { Scoping/ } \\
\text { syntheses of } \\
\text { evidence }\end{array}$ & General & Governance \\
\hline $\begin{array}{l}\text { Social } \\
\text { development; } \\
\text { conflict }\end{array}$ & $\begin{array}{l}\text { Child, early and forced marriage } \\
\text { in fragile and conflict affected } \\
\text { states }\end{array}$ & $\begin{array}{l}\text { Single } \\
\mathrm{HDQ}\end{array}$ & $\begin{array}{l}\text { Context/ } \\
\text { conflict } \\
\text { analysis }\end{array}$ & $\begin{array}{l}\text { Programme } \\
\text { design/ }\end{array}$ & General & $\begin{array}{l}\text { Social } \\
\text { Development }\end{array}$ \\
\hline
\end{tabular}




\begin{tabular}{|c|c|c|c|c|c|c|c|}
\hline & & & & $\begin{array}{l}\text { business } \\
\text { case }\end{array}$ & & & \\
\hline $\begin{array}{l}\text { Social } \\
\text { development; } \\
\text { governance }\end{array}$ & $\begin{array}{l}\text { Social safety nets in fragile and } \\
\text { conflict-affected states }\end{array}$ & $\begin{array}{l}\text { Single } \\
\mathrm{HDQ}\end{array}$ & $\begin{array}{l}\text { Intervention } \\
\text { analysis }\end{array}$ & $\begin{array}{l}\text { Programme } \\
\text { design/ } \\
\text { business } \\
\text { case }\end{array}$ & General & & Other \\
\hline $\begin{array}{l}\text { Social } \\
\text { development; } \\
\text { governance }\end{array}$ & & $\begin{array}{l}\text { Single } \\
\text { HDQ }\end{array}$ & $\begin{array}{l}\text { Context/ } \\
\text { conflict } \\
\text { analysis; } \\
\text { intervention } \\
\text { analysis }\end{array}$ & $\begin{array}{l}\text { Scoping/ } \\
\text { syntheses of } \\
\text { evidence }\end{array}$ & $\begin{array}{l}\text { Middle East } \\
\text { and North } \\
\text { Africa }\end{array}$ & Libya & Other \\
\hline $\begin{array}{l}\text { Social } \\
\text { development; } \\
\text { health; } \\
\text { conflict }\end{array}$ & $\begin{array}{l}\text { Conflict situations and domestic } \\
\text { violence }\end{array}$ & $\begin{array}{l}\text { Single } \\
\mathrm{HDQ}\end{array}$ & $\begin{array}{l}\text { Context/ } \\
\text { conflict } \\
\text { analysis }\end{array}$ & $\begin{array}{l}\text { Inform policy } \\
\text { work }\end{array}$ & General & & $\begin{array}{l}\text { Social } \\
\text { Development }\end{array}$ \\
\hline $\begin{array}{l}\text { Social } \\
\text { development; } \\
\text { humanitarian }\end{array}$ & $\begin{array}{l}\text { Social Capital and Coping with } \\
\text { Crisis in Yemen }\end{array}$ & $\begin{array}{l}\text { Single } \\
\mathrm{HDQ}\end{array}$ & $\begin{array}{l}\text { Context/ } \\
\text { conflict } \\
\text { analysis }\end{array}$ & $\begin{array}{l}\text { Programme } \\
\text { design/ } \\
\text { business } \\
\text { case }\end{array}$ & $\begin{array}{l}\text { Middle East } \\
\text { and North } \\
\text { Africa }\end{array}$ & Yemen & $\begin{array}{l}\text { Social } \\
\text { Development }\end{array}$ \\
\hline $\begin{array}{l}\text { Social } \\
\text { development; } \\
\text { humanitarian; } \\
\text { conflict }\end{array}$ & $\begin{array}{l}\text { Gender and conflict in Ukraine } \\
\text { (humanitarian and social } \\
\text { impacts) }\end{array}$ & $\begin{array}{l}\text { Single } \\
\mathrm{HDQ}\end{array}$ & $\begin{array}{l}\text { Context/ } \\
\text { conflict } \\
\text { analysis }\end{array}$ & & $\begin{array}{l}\text { Europe and } \\
\text { Central Asia }\end{array}$ & Ukraine & Other \\
\hline
\end{tabular}




\section{References}

Bjarnegård, E., Melander, E., \& True, J. (2020). Women, peace and security: The sexism and violence nexus. Folke Bernadotte Academy, Peace Research Institute Oslo (PRIO) \& UN. https://www.unwomen.org//media/headquarters/attachments/sections/library/publications/2020/new-insights-on-wps-thesexism-and-violence-nexus-en.pdf?la =en\&vs=5300

Cockburn, C. (2004). The continuum of violence: a gender perspective on war and peace. In Giles. \& Hyndman, J. (eds.) Sites of Violence: Gender and Conflict Zones. University of California Press.

Fisher, S., Ibrahim Abdi, D., Ludin, J., Smith, R., Williams, S., Williams, S. (2000). Working with conflict: skills and strategies for action. Zed books.

https://books.google.co.uk/books?id=YCPEoKBIS54C\&printsec=frontcover\#v=onepage\&q\&f=fals e

Carbonari, F., Willman, A., Manolio, F., Reinach, S. \& Marques, D. (2020) A Review of the Evidence and a Global Strategy for Violence Prevention. Pathfinders.

https://www.sdg16hub.org/system/files/2020-10/6c192f_f6036b2b1ecf4fd1a3d7687ff7098a46.pdf

Galtung, J. (1969). Violence, peace, and peace research. Journal of Peace Research, 6(3), 16791. https://www.jstor.org/stable/422690

Galtung, J. (1990). Cultural violence. Journal of peace research, 27(3), 291-305.

https://journals.sagepub.com/doi/10.1177/0022343390027003005

Herbert, S. (2014). Links between gender-based violence and outbreaks of violent conflict. GSDRC, University of Birmingham. https://gsdrc.org/publications/links-between-gender-basedviolence-and-outbreaks-of-violent-conflict/

Herbert, S. (2017). Conflict analysis: Topic guide. GSDRC, University of Birmingham. https://gsdrc.org/topic-guides/conflict-analysis/

Herbert, S. (2021) How rapid research supports evidence-based policymaking. Institute of Development Studies (IDS) [Blog] IDS. https://www.ids.ac.uk/opinions/how-rapid-researchsupports-evidence-based-policymaking/

K4D (2021) Annual Review March 2021: Evidence-Based Knowledge for Development (K4D) - a service delivering evidence and knowledge through collaborative lesson learning. Internal document

The K4D helpdesk service provides brief summaries of current research, evidence, and lessons learned. Helpdesk reports are not rigorous or systematic reviews; they are intended to provide an introduction to the most important evidence related to a research question. They draw on a rapid deskbased review of published literature and consultation with subject specialists.

Helpdesk reports are commissioned by the UK Department for International Development and other Government departments, but the views and opinions expressed do not necessarily reflect those of DFID, the UK Government, K4D or any other contributing organisation. For further information, please contacthelpdesk@k4d.info. 
Price, R. (2021, forthcoming) Synthesis of K4D research around climate change and related issues. Brighton, UK: Institute of Development Studies. Forthcoming

Quak, E. (2021). K4D's Work on the Indirect Impacts of Covid-19 in Low- and Middle-Income Countries. K4D Helpdesk Report No. 1018. Brighton, UK: Institute of Development Studies. https://opendocs.ids.ac.uk/opendocs/handle/20.500.12413/16724

\section{Suggested citation}

Herbert, S. (2022). K4D's work on conflict, violence, and peace (2016-2021). Brighton, UK: Institute of Development Studies. DOI: 10.19088/K4D.2021.131

\section{About this report}

This report is based on twelve days of desk-based research. The K4D research helpdesk provides rapid syntheses of a selection of recent relevant literature and international expert thinking in response to specific questions relating to international development. For any enquiries, contact helpdesk@k4d.info.

K4D services are provided by a consortium of leading organisations working in international development, led by the Institute of Development Studies (IDS), with Education Development Trust, Itad, University of Leeds Nuffield Centre for International Health and Development, Liverpool School of Tropical Medicine (LSTM), University of Birmingham International Development Department (IDD) and the University of Manchester Humanitarian and Conflict Response Institute (HCRI).

This report was prepared for the UK Government's Foreign, Commonwealth and Development Office (FCDO) and its partners in support of pro-poor programmes. Except where otherwise stated, it is licensed for non-commercial purposes under the terms of the Open Government Licence v3.0. K4D cannot be held responsible for errors, omissions or any consequences arising from the use of information contained in this report. Any views and opinions expressed do not necessarily reflect those of FCDO, K4D or any other contributing organisation.

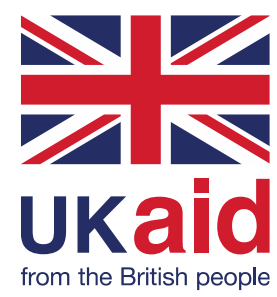

(C) Crown copyright 2022. 